\title{
KONSEP MAKANAN HALAL DALAM TINJAUAN SYARIAH DAN TANGGUNG JAWAB PRODUK ATAS PRODUSEN INDUSTRI HALAL
}

\author{
Muchtar Ali \\ Kementerian Agama Republik Indonesia \\ Jl. M. H. Thamrin No. 6, Menteng, Jakarta Pusat \\ E-mail: muchtarali@kemenag.go.id
}

\begin{abstract}
The Concept of Halal Food in Sharia Perspective and Product Responsibility of Halal Industry. Sharia provisions regarding halal and haram food, beverages, and goods are integral parts of Islamic teachings. Halal and haram foods also have become a necessity related to the comfort and safety of the Muslims as the largest consumers in Indonesia. This need should be enforced by halal industry. Every manufacturer of halal foods should have an understanding and awareness to ensure their halal products by implementing a Halal Assurance System as the implementation of sharia concept of halal and haram on food and drinks. The violation of Halal Assurance System by the manufacturer will be subject to product liability, both legally and morally.
\end{abstract}

Keywords: halal, haram, manufacturer, product liability.

\begin{abstract}
Abstraksi: Konsep Makanan Halal dalam Tinjauan Syariah dan TanggungJawab Produk Atas Produsen Industri Halal. Ketentuan syariah mengenai halal dan haramnya makanan, minuman dan barang gunaan bagian integral dari ajaran Islam. Halal dan haramnya makanan juga telah menjadi kebutuhan, dan berkaitan dengan kenyamanan dan keselamatan umat Islam sebagai konsumen terbesar di Indonesia yang perlu ditegakkan oleh para produsen industri halal. Setiap produsen industri makanan halal sewajibnya memiliki pemahaman dan kesadaran untuk menjamin kehalalan produknya yang diedarkan dengan menerapkan Sistem Jaminan Halal (SJH) sebagai implementasi konsepsi syariah tentang kaedah halal dan haram pada makanan dan minuman. Perbuatan pelanggaran terhadap SJH oleh produsen akan dapat diterapkan tanggung gugat produk (product liability) baik secara hukum dan moral.
\end{abstract}

Kata Kunci: halal, haram, produsen, tanggung gugat produk.

\section{Pendahuluan}

Makanan merupakan keperluan yang penting bagi manusia. Dalam memilih makanan, kebanyakan konsumen lebih mengutamakan cita rasa makanan dan kurang memperdulikan kehalalannya. Sejalan dengan ajaran syariah Islam konsumen Muslim menghendaki agar produk-produk yang akan dikonsumsi terjamin kehalalannya dan kesuciannya. Dalam ketentuan halal, haram, thayyib, dan syubhat terkandung nilai spritual serta mencerminkan keluhuran budi pekerti dan akhlak seseorang. Oleh karenanya, syariah Islam menaruh perhatian yang sangat tinggi dalam menentukan makanan mimunan itu halal, haram, atau meragukan (syubhat).

Indonesia sebagai negeri dengan penduduk Muslim terbesar di dinia, yaitu 190.113.060 dari total jumlah penduduk 237.641.326 jiwa atau 80\% (BPS, 2013), isu

Naskah diterima: 5 April 2016; Direvisi: 12 Juni 2016; Disetujui untuk diterbitkan: 18 Juni 2016. makanan halal menjadi isu yang sensitif bagi masyarakat. Selain itu, Indonesia juga merupakan pasar konsumen Muslim yang sangat potensial. Pemerintah memiliki tanggung jawab besar melindungi masyarakat secara keseluruhan, terutama konsumen atas kehalalan produkproduk yang beredar dan dipasarkan. Demikian juga para produsen, secara hukum, etika, dan moral berbisnis dituntut memiliki tanggung jawab produk (product liability) atas produk yang diedarkan jika terdapat cacat, membahayakan, atau tidak memenuhi standar yang telah diperjanjikan.

\section{Terminologi Halal}

Kata "halal" dan "haram" merupakan istilah Alquran dan ini digunakan dalam pelbagai tempat dengan konsep berbeda, dan sebagiannya berkaitan dengan makanan dan minuman. Kedua kata tersebut juga digunakan dalam Hadis Nabi Saw. Halal secara bahasa, menurut sebagian pendapat, berasal dari akar kata الإلحل yang artinya (الإباحة) artinya sesuatu yang dibolehkan 
menurut syariat ${ }^{1}$. Al-Jurjani menulis, kata "halal" berasal dari kata الحل yang berarti " terbuka" (الفتح). Secara istilah, berarti setiap sesuatu yang tidak dikenakan sanki penggunaannya atau sesuatu perbuatan yang dibebaskan syariat untuk dilakukan." 2 Menurut Abû

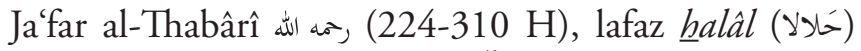

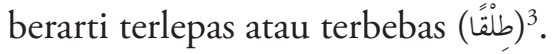

Abû Muhammad al- $\underline{\text { Hu} u s a y n ~ i b n ~ M a s i ̂ u d ~ a l-B a g h a w i ̂ ~}$ (436-510H) dari mazhab Syafi'i, berpendapat

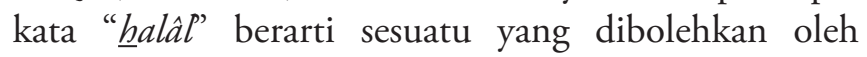
syariat karena baik. ${ }^{4}$ Muhammad ibn 'Ali al-Syawkânî (1759-1834 H) berpendapat, dinyatakan sebagai halal karena telah terurainya simpul tali atau ikatan larangan yang mencegah. ${ }^{5}$ Senada dengan pendapat al-Syawkânî (1759-1834 H). Dari kalangan ulama kontemporer, seperti Yusuf al-Qaradhawî, mendifiniskan halal sebagai sesuatu yang dengannya terurailah buhul yang membahayakan, dan Allah memperbolehkan untuk dikerjakan. ${ }^{6}$ Sementara 'Abd al-Raḩmân ibn Nâshir ibn al-

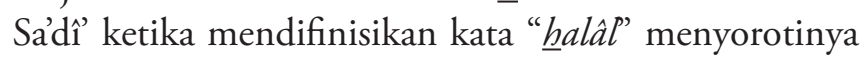
kepada bagaimana memperolehnya, bukan dengan cara ghashab, mencuri, dan bukan sebagai hasil muamalah yang haram atau berbentuk haram. ${ }^{7}$

Dari beberapa penjelasan tersebut di atas, dapat ditarik kesimpulan halal adalah sesuatu yang diperbolehkan oleh syariat untuk (i) dilakukan, (ii) digunakan, atau (iii) diusahakan, karena telah terurai tali atau ikatan yang mencegahnya atau unsur yang membahayakannya dengan disertai perhatian cara memperolehnya, bukan dengan hasil muamalah yang dilarang.

Tentang lafadz "thayyib"-yang disebutkan pada surah al-Baqarah [2] ayat 168-menurut Imam Malik adalah berarti "halal", sebagai penguat firman Allah

${ }^{1}$ Muhammad Rawas Qal'ajî dan Muhammad Shâdiq Qanaybî, Mujjam Lughah al-Fuqahâ, (Bayrût: Dâr al-Fikr, 1405H-1985M), Cet. I, h. 184.

2 'Alî ibn Muhammad ibn 'Alî al-Jurjanî, Al-Tárîfât, Tahquîq Ibrâhîm al-Abyarî, (Bayrût: Dâr al-Kitâb al-'Arabî, 1405H), Cet I, h. 124, redaksinya yaitu:

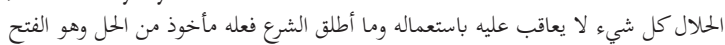

${ }^{3}$ Muhammad ibn Jarîr ibn Yazîd ibn Katsîr ibn Ghâlib al-Amalî Abû Ja 'far al-Thabârî, Jâmi' al-Bayân fî Táwîl al-Qur'ân, di-tahquîq oleh Ah̆mad Muhammad Syakir, Penerbit Mu’assasah al-Risâlah, cetakan Malik Fahad, cet. I, selanjutnya ditulis Ibn Katsîr.

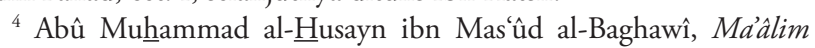
Tanzîl, (Dâr Thibah, Majma’ Mâlik Fahd, 1417 H-1997 M), Cet. IV, jilid I, h. 180.

5 Imam al-Syawkânî, Fath al-Qâdir, (Bayrût: Dâr al-Mảrifah, 2007), Cet. IV, h. 216.

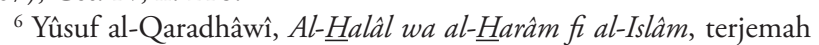
Wahid Amadi dkk, Halal Haram dalam Islam, (Solo: Era Intermedia, 1424H-2003 M), Cet III, h. 31.

7 'Abd al-Raḩmân ibn Nashir ibn al-Sa'di, Taysîr al-Karîm al-Rạnmân fi Tafsîr Kalm al-Mannân, di-tahqqîq oleh 'Abd al-Rahmân ibn Ma'lâ alLuwayhik, (Mu'assasah al-Risâlah, Mâlik Fahd, 1420H-2000H), Cet. I, h. 80. Selanjutnya ditulis denga al-Sa’dî. "balâl-an". ${ }^{8}$ Dari pendapat Imam Malik ini jelas bahwa halal dan thayyib bertemu salam satu makna sebagai penguat (takid) perbedaan lafaz. ${ }^{9}$ Al-Syâf ${ }^{\prime}$ i, sebagaimana dikutip al-Syawkânî adalah yang melezatkan. Imam al-Thabarî $(224-310 \mathrm{H})$ berpendapat bahwa arti lafaz "thayyib" dalam ayat ini adalah sesuatu yang suci tidak mengandung najis dan tidak juga haram. ${ }^{10}$ Menurut Abû Bakr Ibn al-Arabî, "thayyib" adalah kebalikan dari "alkhabitts" (الخبيث), berarti yang jelek atau buruk. Kemudian ia menambahkan bahwa pengertian "thayyib" kembali kepada dua arti. Pertama, sesuatu yang layak bagi bagi jasad atau tubuh dan dirasakan lezatnya. Kedua, sesuatu

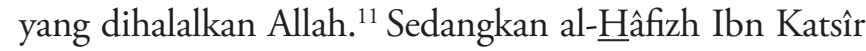
menjelaskan bahwa lafaz "thayyib" dalam ayat ini yakni yang lezat bagi diri manusia tidak membahayakan kepada badan dan akal.

Dasar yang digunakan untuk menunjukkan keharusan mengonsumsi makanan dan minuman, tumbuhan dan binatang/hewan yang telah halal lagi thayyib (baik) tercantum dalam Alquran dan Hadis. Contoh perintah untuk mengonsumi dan memanfaatkan yang halal yaitu: Qas. al-Baqarah [2]: 168 dan 172, Q.s. al-Nahl [16]: $4^{12}$, al- Mầidah [5]: 87 dan 88, al-Anfâl [8]: 69, al-Nahl [16]: 114. Dalam ayat-ayat ini kata "halal" menjadi dasar perintah mengonsumsi makanan dan minuman yang halal dan thayyib.

Mengenai surah al-Baqarah [2]:168 yang berbunyi:

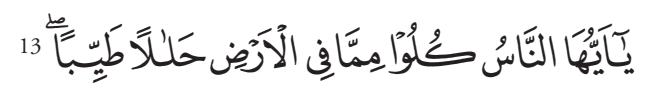

Al-Sảdî menjelaskan bahwa tunjukan (khithâb) ayat ini sebagai seruan yang ditujukan kepada seluruh manusia, baik Mukmin maupun Kafir. ${ }^{14}$ Demikian juga Muhammad 'Ali al-Shâbûnî pun memahami ayat tersebut

\footnotetext{
${ }^{8}$ Imam al-Syawkânî, Fath al-Qâdir, h. 216.

${ }^{9}$ Abû 'Abd Allâh Muhammad Ahmad al-Anshârî al-Qurthûbî, AlJâmi' li Ahkâm al-Qur'an, (Bayrût: Dâr al-Fikr, t.th), Jilid I, h. 195.

${ }^{10}$ Muhamamad ibn Jarîr ibn Yazîd ibn Katsîr ibn Ghâlib al-Amalî Abû Ja'far al-Thabari, Jami' al-Bayân fi Táwil al-Qur'ân, selanjutnya

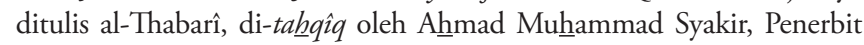
Muassah al-Risalah, Malik Fahad. Cet I . Selanjutnya ditulis al-Thabarî.

${ }^{11}$ Abû Bakr Muhammad ibn 'Abd Allâh Ibn al-'Arabî, Ahkam AlQur'an, (Bayrût: Dâr al-Fikr, t.th), jilid II, h. 32. Selanjutnya ditulis Ibn al-'Arabî.

${ }^{12}$ John L. Esposito, Ensiklopedi Oxford Dunia Islam Modern, Penerjemah, Eva YN, dkk, (Bandung: Penerbit Mizan, 2001), Cet. I, h. 323.

${ }^{13}$ Sebagian ulama tafsir memberikan keterangan bahwa ayat ini diturunkan pada Kabilah Tsaqif dan Khuza’ah dan Bani Madlaj yang berkenaan dengan mereka mengharamkan atas diri mereka pada sebagian binatang ternak sebagaimana diceritakan oleh al-Qurthubî di dalam tafsirnya. Namun demikian, terdapat kaidah yang menyebutkan bawa suatu redaksi berlaku pada keumuman lafaz bukan pada kekhususan sebab. Lihat: Imam al-Qurthubî, Al-jâmi' li A $\underline{b k a ̂ m}$ alQur'ân, (Beirut: Mu’assasah al-Risâlah, 2006), Cet. I, h. 195.

14 'Abd al-Rahmân ibn Nashir ibn al-Sa'di, Taysîr al-Karîm alRahmân, h. 80.
} 
dengan pemahaman yang sama bahwa yang menjadi $k h i t h a ̂ b$ ayat tersebut adalah umum, yaitu untuk semua manusia agar mereka mengonsumsi yang Allah telah halalkan bagi mereka. ${ }^{15}$ Kemudian al-Sa’dî menambahkan penjelasannya dengan menghubungkan ayat tersebut dengan ayat sebelumnya. Pertama, Q.s. al-Baqarah [2]: 163 ayat ini menerangkan keesaan Allah disertai bukti-bukti kekuasaan-nya, maka Allah telah menganugerahkan nikmat-Nya kepada mereka, yaitu agar mereka memakan apa yang terdapat di muka bumi, berupa biji-bijian, buah-buahan, hewan yang halal diperoleh secara halal, bukan dengan mengambil cara paksa dan tidak pula dengan mencuri, dan bukan hasil usaha yang haram dengan cara yang haram atau sesuatu yang telah ditentukan keharamannya. ${ }^{16}$

Kedua, Q.s. al-Baqarah [2]: 172:

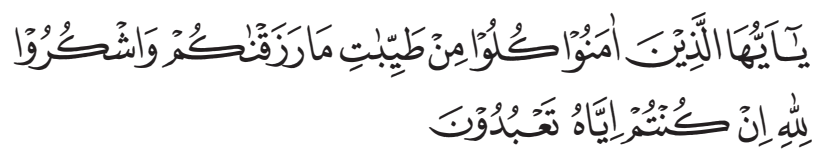

Bagi al-Qurthubi, ayat tersebut merupakan penguat perintah mengonsumsi yang halal dan yang thayyib. Di sini Allah mengkhususkannya bagi orang Mukmin.

Ketiga, Q.s. al-Mu’minûn [23]: 51:

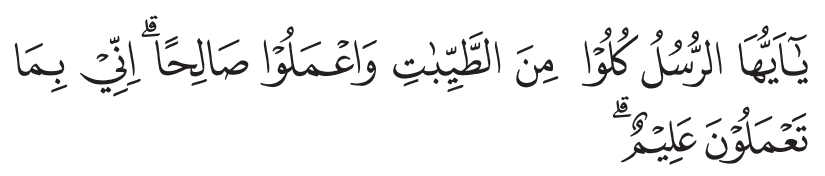

Allah memerintahkan seluruh Rasul-Nya mengonsumsi makanan halal dan melakukan amal salih. Dengan ayat ini semakin jelas bahwa mengonsumsi yang halal bagian dari dari perintah syar'i dan amal salih, maka para Rasul pun telah melaksanakannya. Dari sumber ayat-ayat Alquran di atas dapat dipahami bahwa mengonsumsi makanan dan minuman yang baik lagi halal merupakan bagian dari perintah. Atau dengan redaksi lain, ketentuan halal dan haram terintegrasi ke dalam suatu kerangka keimanan (akidah), syariat, dan akhlak. Dari aspek syariah, bagi kaum Muslim, menurut John L. Esposito syariat menuntut ketaatan dan merupakan fokus keimanan ${ }^{17}$. Mengenai ketaatan pada hukum

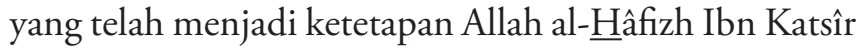
menuturkan keterangan yang penting diperhatikan ketika memberi penjelasan Q.s. al-Ahzâb [31]: 36, yaitu:

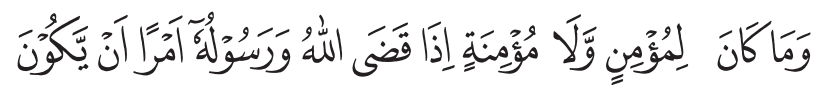

${ }^{15}$ Muhammad 'Alî al-Shâbûnî, Shafwah al-Tafâsîr, (Bayrût: Dâr alFikr, tt.th), jilid I, h. 113.

16 'Abd al-Rahmân ibn Nashir ibn al-Sa'di, Taysîr al-Karîm alRạmân, h. 80 .

${ }^{17}$ John L. Esposito, Esposito-Hukum, h. 192, vol. 2.

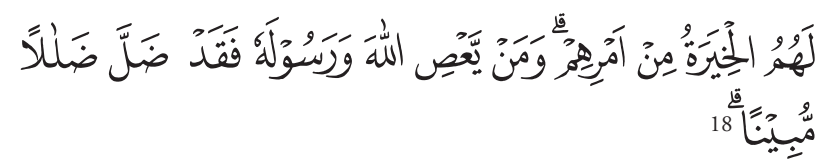

Menurut al-Hâffizh Ibn Katsîr bahwa pada ayat tersebut berlaku umum pada semua persoalan, yaitu sesungguhnya jika Allah dan Rasul-Nya telah menetapkan suatu hukum, maka tidak patut bagi seseorang memperselisihkannya dan juga tidak dibenarkan ada upaya untuk menghindar, baik berupa pendapat maupun perkataan. Al- $\underline{\text { Hâfizh }}$ mengemukakan dalil yang menjadi landasan pendapatnya adalah Q.s. al-Nisầ [4]; 65 dan Hadis Nabi Saw. yaitu:

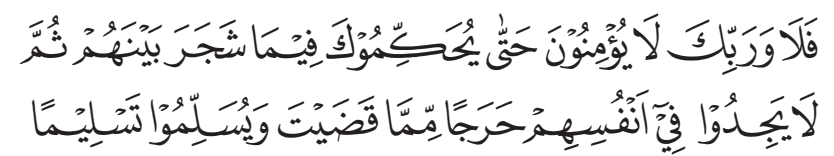

Mengenai ayat tersebut al-hafidz lebih lanjut menjelaskan bahwa dalam ayat bahwa Allah bersumpah dengan nama-Nya yang Mulia dan Suci bahwa seseorang tidaklah beriman sehingga Rasulullah dijadikannya sebagai hakim dalam segala urusan. Seluruh yang telah ditetapkan oleh Rasulullah adalah haq dan wajib dilaksanakan baik secara lahir maupun batin dan tidak diperkenankan ada perasaan berat atau susah. Adapun Hadis yang memperkuat pendapatnya, yaitu:

$$
\text { تبعًا لما جئت بهي بيده، لا يؤمن أحدكم حتى يكون هواه }
$$

Demi jiwaku (Muhammad) yang berada di tanganNya, tidaklah beriman seseorang kamu sehingga hawa nafsunya mengikuti apa yang aku bahwa.

Pendapat yang senada dengan pendapat al- $\underline{\text { Hâfizh }}$ seperti ditulis al-Syawkânî dalam Fath al-Qâdir bahwa yang lebih utama dalam hal ini adalah membawa pengertiaan ini kepada makna umum dan tidak mengkhususkannya dengan individu atau suatu macam saja. ${ }^{20}$

Lebih jauh jika dikaji lebih dalam, memang dalam diri manusia senantiasa ada ketegangan dan tarikmenarik antara kekuatan kebaikan dan kekuatan

${ }^{18}$ Sebab turunnya ayat ini sebagaimana ditulis oleh Jalâl al-Dîn al-Suyûthî berdasarkan Hadis yang diriwayatkan oleh al-Thabrânî dengan sanad yang shahbîh dari Qatâdah telah berkata, Nabi Saw. telah melamar Zainab untuk Zaid, Zainab telah mengira bahwa Nabi Saw. melamar untuk dirinya sendiri, maka ketika ia mengetahui bahwa Nabi Saw. melamar untuk Zaid, maka Zainab enggan menerima lamaran. Maka Allah telah menurunkan ayat tersebut. Dalam riwayat lain yang diriwayatkan oleh Ibn Jarîr dari Ibn 'Abbâs berkata, "Nabi Saw. telah melamar Zainab ibnt Jahsyin untuk Zaid ibn $\underline{\text { Haritsah, }}$ maka Zainab memandang rendah Zaid dan berkata, "Saya lebih baik keturunannya dibandingkan dia", maka Allah menurunkan ayat tersebut. Lihat Jalâl al-Dîn al-Suyûthî dalam Lubâb al-Nuqûl fi Asbâb al-Nuzûl, (Maktabah al-Qâhirah: al-Duwaliyah, t.th), h. 351.

${ }^{19}$ Abî al-Fidâ al-Hâafizh ibn Katsîr al-Dimasyqî, Tafsîr al-Qur'ân al'Azhîm, jilid III dan II, (bayrût: Dâr al-Fikr, 1412H-1992M), h. 643.

${ }^{20}$ Imam al-Syawkânî, Fath al-Qâdir, h. 217 
kejahatan. Seperti ditulis oleh Yusuf Ali, ketegangan itu berpangkal pada adanya emosi pada manusia yang dapat mendorongnya kepada kebaikan dan kepada kejahatan sekaligus. Dan sejak penciptaannya, manusia telah diberi petunjuk oleh Allah tentang adanya dua jalan hidup, yang benar dan salah, namun manusia enggan menempuh jalan yang sulit, yaitu jalan kebenaran. Dorongan untuk mencari jalan yang mudah itu membuat manusia terbuka pada godaan-godaan. Tugas untuk menggoda itulah "konsesi" yang diberikan oleh Tuhan kepada setan terkutuk, sampai hari kiamat. Bila ditelusuri lebih jauh mengenai Q.s. al-Baqarah [2]: 168 sebagaimana telah dikutip di atas, pada ujung ayat

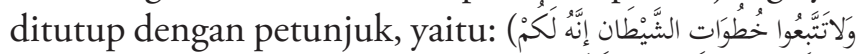

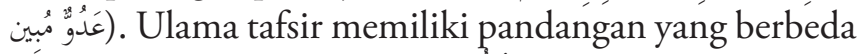

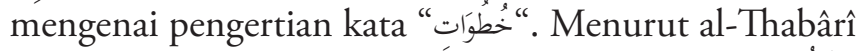

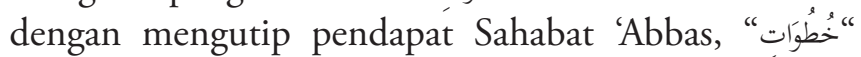
berarti perbuatan. Sementara Mujâhid mengartikan

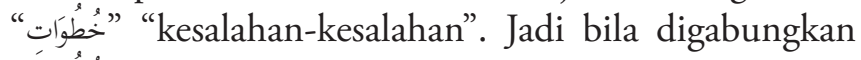

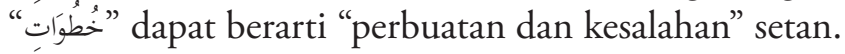

Beda pendapat dengan di atas, menurut al-Qurthubî,

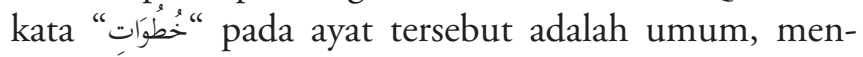
cakup setiap yang di luar Sunah dan syariah, seperti bidah dan maksiat. ${ }^{21}$

Al-Thabârî menjelaskan arti larangan mengikuti “" حُطوَات setan, menurut dia adalah larangan mengikuti jalan dan jejak setan yang menyelisihi ketaatan kepada Allah..$^{22}$ Dengan demikian dapat disebut, bahwa Alquran memerintahkan kaum muslim untuk mengonsumsi rezki Allah yang halal dan thayyib, dan menjauhi sesuatu yang telah diharamkan. Karena pelanggaran terhadap aturanaturan Allah akan mendatangkan penyesalan yang dalam, termasuk pelanggaran terhadap aturan mengenai makan.

Dari aspek kesejarahan penuturan Alquran mengenai kisah Adam. Dalam Alquran dituturkan perintah Allah kepada Adam dan istrinya Hawa, untuk tinggal di surga (jannah) dan menikmati segala makanan yang ada di sana sesuka hati. Namun keduanya dipesan agar tidak mendekati sebuah pohon tertentu. Jika mereka mendekatinya mereka akan tergolong orang-orang yang zalim. Tetapi setan berhasil membujuk dengan mengatakan bahwa ia hendak menunjukkan Adam pohon keabadian (syajarah al-khuld) dan kekuasaan (mulk) yang tidak bakal sirna. Maka setelah Adam dan istrinya memakan buah pohon terlarang itu, keduanya pun menyadari bahwa aurat mereka nampak mata (telanjang), kemudian segera mengambil dedaunan surga untuk menutupinya. Karena pelanggaran mereka itu, Adam dan Hawa diperintahkan turun dari surga,

${ }^{21}$ Abû 'Abd Allâh Muhammad Ahmad al-Anshârî al-Qurthûbî, $A$ Jâmi' li Aḷkâm al-Qur'an, h. 301.

${ }^{22}$ Ibid. diusir ke bumi. Itulah bagian dari pelajaran dari Allah yang hendaknya direnungkan oleh manusia secara sungguh-sungguh. ${ }^{23}$

Memang terdapat ahli tafsir ulama yang tidak sependapat jika Adam diperintahkan turun ke bumi karena pelanggaran. Menurut al-Râzî bahwa perintah kepada Adam dan Hawa untuk turun dari surga bukanlah sebuah hukuman atas pelanggaran mereka berdua, melainkan justru untuk melaksanakan janji Tuhan yang mula pertama, yaitu pengangkatan Adam sebagai khalifah-Nya di bumi Allah.

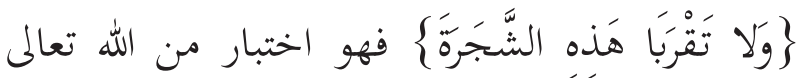

$$
\begin{aligned}
& \text { وامتحان لآدم الكتاب: تفسير القرآن العظيم }
\end{aligned}
$$

Apabila dikaji lebih jauh, memang spirit yang terkadung dalam norma haram dan larangan tidaklah berkaitan dengan hal-hal najis semata, bahkan lebih dari itu mencakup segala sesuatu yang dapat membahayakan bagi badan manusia atau anggota tubuh lainnya, meskipun zat itu berasal dari benda-benda yang suci, misalnya tumbuhan hasyîs (sejenis ganja) dan opium. Alquran tidak pernah menggunakan kata haram..$^{24}$

Dasar penetapan apa yang dimaksud dengan pengertian halal dan haram dari Hadis yaitu riwayat dari Salman al-Farisi bahwa Nabi Saw. ditanya tentang minyak samin, keju, dan jubah dari kulit binatang dapat dicatat mengenai "halal, haram, dan syubhat yang memiliki keterkaitan dengan makanan dan minuman. Beliau menjawab:

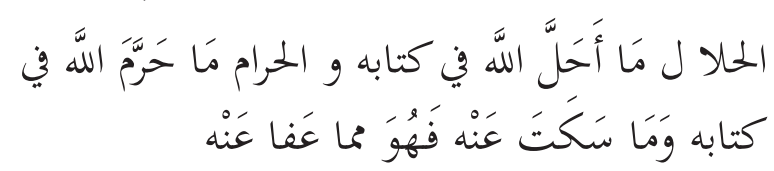

Yang halal adalah segala sesuatu yang Allah halalkan dalam Kitab-Nya, dan yang haram adalah segala sesuatu yang Allah haramkan dalam Kitab-Nya. Sedangkan apa yang didiamkan-Nya maka ia termasuk yang dimaafkan kepada kalian.” (H.r. al-Tirmidzî dan Ibn Mâjah)

Terdapat Hadis lain yang menyuruh mematuhi ketentuan halal dan haram, termasuk dalam mengonsusmi makanan dan minuman halal yaitu:

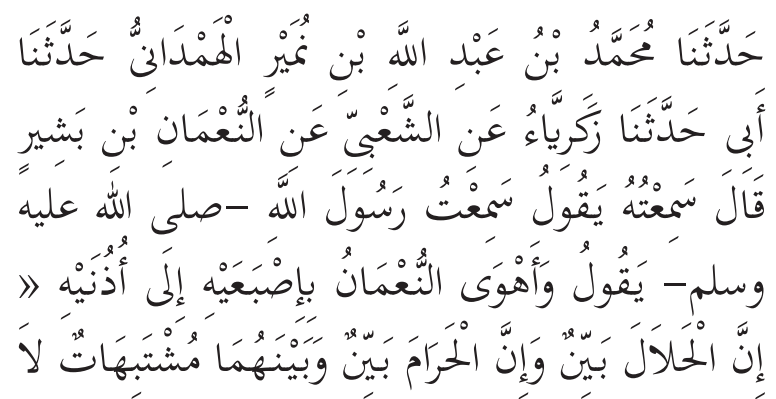

${ }^{23}$ Nurcholis Madjid, Makna Kejatuhan Manusia ke Bumi, dalam Islam Agama Peradaban, (Jakarta: Paramadina, 20000, Cet II., h. 149.

${ }^{24}$ Kamil Musa: h. 163. Paragraf 3. 


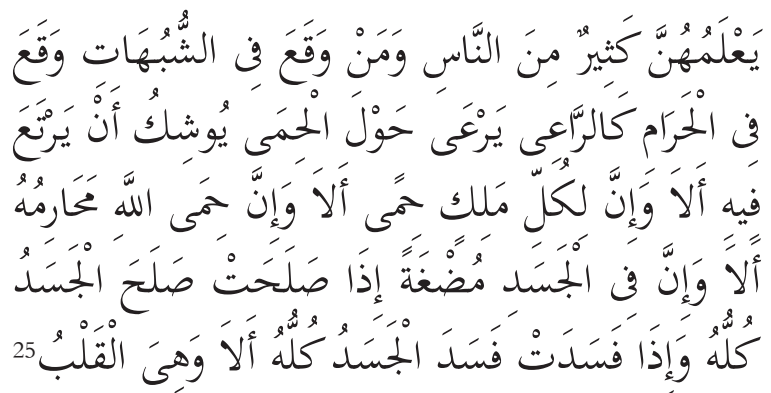

Dari Muhammad bin Abdillah ibn Numair al-Hamdani, dari ayahku dari Zakariyya dari Sya’bi dari al-Nu'man bin Basyir telah berkata saya telah mendengar Rasulullah Saw. dan dia bahwa dengan telunjuknya ke arah telinganya, "Sesungguhnya yang halal itu jelas, yang haram jelas. Dan di antara keduanya ada masalah syubhat, kebanyakan manusia/orang tidak mengetahuinya. Karena itu maka barang siapa menjaganya/bertakwa terjerumus dalam syubhat, berarti dia telah membebaskan agama dan kehormatannya. Dan barang siapa terjerumus pada sesuatu di dalam syubhat, berarti hampir terjerumus ke dalam yang haram. Sebagaimana jika seseorang menggembala ternaknya di sekitar Hima (tempat/area milik raja yang dijaga/dilindungi dan terlarang dimasuki orang lain dan siapa yang memasukinya maka akan dijatuhi saksi hukuman). Ketahuilah bahwa sesungguhnya setiap raja memiliki hima, ketahuilah bahwa hima Allah adalah larangan-larangan-Nya”. ${ }^{26}$ (H.r. Muslim).

Menurut al-Nawâwî para ulama telah bersepakat mengenai keagungan kedudukan Hadis ini dan faidahnya, bahkan menurut dia, Hadis merupakan satu di antara Hadis-Hadis yang menjadi dasar (mashdar) Islam. Adapun sebabnya, karena menurut para ulama pada Hadis ini Rasulullah Saw. mengingatkan agar memperbaiki makanan, minuman, pakaian, dan lainnya. Juga hendaknya seorang Muslim meninggalkan hal-hal yang syubhat karena sikap demikian dapat memelihara agama dan kehormatannya.

Ditambahkan lagi oleh al-Nawawi pada Hadis ini ada penguatan untuk upaya pembenahan/perbaikan hati dan pemeliharaan hati dari hal-hal yang dapat merusaknya, karena pada Hadis ini Rasulullah menjadikan kebaikan hati dan kerusakannya amat berkaitan dengan kebaikan dan kerusakan hati. ${ }^{27}$ Dengan demikian Hadis ini menjadi salah satu dalil yang memperkuat pentingnya perhatian terhadap ketentuan halal dan haram dalam mengonsumsi makanan dan minuman serta berpakaian, karena akan berdampak pada tubuh dan hati seseorang.

${ }^{25}$ Hadis riwayat Imam Muslim dalam Syarh Shahîh $\underline{h}$ Muslim, Imam Abî Zakariyyâ Yahyâ ibn Syaraf al-Nawâwî al-Dimasyqî,, (Bayrût: Dâr al-Fikr, 1421H-2000M), Jilid VI, h. 23. Hadis No. 1599. Hadis ini juga diriwayatkan al-Tirmidzî dalam Tuhfah al-Ahwadzî Syarh alMubârak Furî pada bab Tark al-Syubhât, hadis nomor 1250.

${ }^{26}$ Ayat ini terdapat dalam surah al-Baqarah sebagai surah-surah Madaniyah sekalipun didahului dengan kata يأيها الناس

${ }^{27}$ Imam Abî Zakariyyâ Yahyâ ibn Syaraf al-Nawâwî al-Dimasyqî, Syarh Shahîh Muslim, h. 24.

\section{Terminologi Haram}

Sebelum membahas tujuan dan hikmat penetapan halal dan haram, penting lebih dahulu menulis pengertian "haram". Dari sisi bahasa, haram adalah dilarang/terlarang atau tidak diizinkan (المنوع). ${ }^{28}$ Dari sisi istilah, menurut Yûsuf al-Qarâdhawî haram sesuatu yang Allah melarang untuk dilakukan dengan larangan yang tegas, setiap orang yang menentangnya akan berhadapan dengan siksaan Allah di akhirat. Bahkan terkadang ia juga terancam sanksi syariat di dunia. ${ }^{29} \mathrm{Al}$-Sa'di menambahkan, keharaman itu ada dua macam yaitu karena disebabkan zatnya, yaitu jelek dan keji, lawan dari thayyib. Atau haram dikarenakan yang ditampakkannya, yaitu keharaman yang berkaitan dengan hak Allah atau hak hamba-Nya dan ini adalah lawannya halal. ${ }^{30}$

Penyebutan "haram" dengan perubahan bentuknya dari Alquran yang memiliki konteks dengan makanan, minuman dan pakaian terdapat pada surah al-Baqarah (2): 172-73, al-Mâiidah (5): 3, 87, al-An'âm (6) 143, 144, 145, dan 146, al-A'râf (7): 32, 157, al-Nahl (16): $115,116,118$.

Sumber Alquran dalam bentuk pengharaman, misalnya penetapan keharaman bangkai, darah, daging babi, dan sesuatu yang disembelih dengan menyebut nama selain Allah, pada surah al-Mầidah (5):

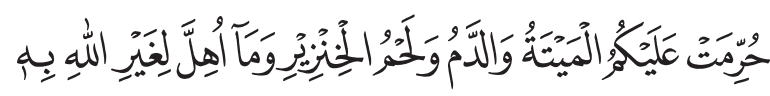

Al-Thabârî menulis pandangan Abû Ja'far bahwa kata "حرمت" pada ayat tersebut menunjukkan Allah telah mengharamkan bangkai. ${ }^{31}$

Hadis yang menjelaskan mengharaman pengharaman, misalnya penetapan Nabi Saw. mengenai keharaman keledai bighal, hewan buas yang bertaring dan setiap burung yang mempunyai cakar. Hadis ini bersumber dari Abû Hurayrah dan Abî Salâmah yang diriwayatkan Tirmizi:

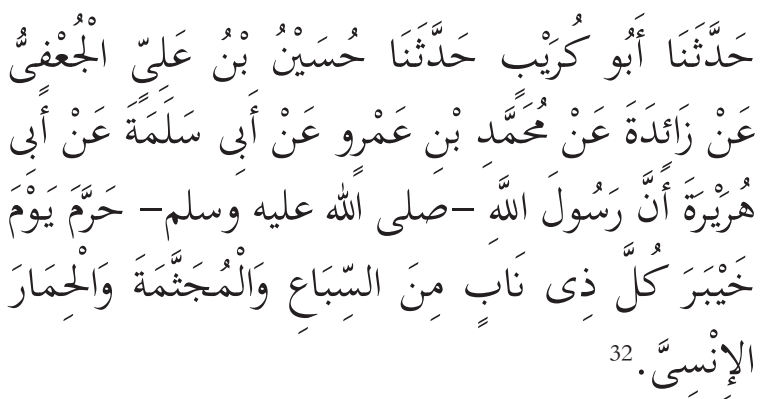

${ }^{28}$ Abû al-Sa'ûd Muhammad ibn Muhammad ibn Musthafâ alImadî, Mufradât al-Qur'ân, versi Maktabah asy Syamilah, h. 315.

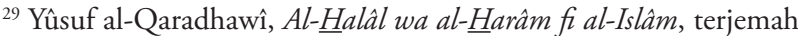
Wahid Amadi dkk, Halal Haram dalam Islam, h. 31.

30 'Abd al-Rahmmân ibn Nashir ibn al-Sa'di, Taysîr al-Karîm al-Rậmân.

${ }^{31}$ Muhammad ibn Jarîr ibn Yazîd ibn Katsîr ibn Ghâlib al-Amalî Abû Ja'far al-Thabari, Jami' al-Bayân fi Ta'wil al-Qur'ân, h. 492.

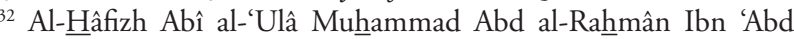


Sesungguhnya Rasulullah Saw pada hari Khaibar telah melarang setiap hewan buas yang bertaring, alMujatsamah, dan himar yang jinak.

Menurut al-Qarâdhawî wilayah keharaman dalam syariat Islam sangatlah sempit, sebaliknya, wilayah kehalalan terbentanglah sangat luas. Karena nas (nash) yang datang dengan pengharaman sedikit sekali jumlahnya. Selain itu, sesuatu yang tidak ada nas yang mengharamkan atau menghalalkannya, ia kembali kepada hukum asalnya, boleh. Ia berada dalam wilayah kemaafan Tuhan. ${ }^{33}$

Larangan keras memakan bagkai, darah, daging babi, dan binatang yang disembelih karena selain Allah dapat dipahami pada surah al-Mầidah (5): 3, Q.s. alAn'âm (6): 14. Memang penghraman arak, tuak, dan khamar diterapkan secara bertahap setelah terbentuknya umat Muslim di Madinah. Dispensasi umum terhadap larangan dengan beberapa syarat.

\section{Terminologi Syubhat (Syubuhât)}

Syubhat adalah sesuatu yang tidak jelas kehalalan dan keharamannya karena banyak manusia yang tidak mengetahui hukumnya. Adapun ulama mereka dapat mengetahui hukum dari nas atau qiyâs atau sebagainya, apabila seseorang meragukan sesuatu apakah halal atau haram sementara tidak ada nas dan ijmak sebagai hasil ijtihad mujtahid lalu mendapatkan dalil syar'i-nya lalu dijumpainya halal maka ia menjadi halal, tetapi terkadang ada dalilnya, namun tidak tertutup kemungkinan keraguan (ihtimâl) yang jelas maka lebih utama bersikap wara' dengan meninggalkannya, karena sikap seperti ini merupakan pengamalan sabda Nabi

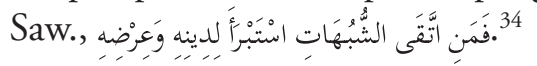

\section{Urgensi Pemahaman Halal, Haram, Syubhat}

Apakah hukum Islam dengan seperangkat hukumnya: wajib, sunah, haram, makruh, dan mubah, mempunyai tujuan tertentu? Ataukah hukum-hukum Islam hanya sekedar perintah, larangan, halal dan haram yang bersifat kepatuhan (ta'abbudî) semata, tanpa tujuan khusus? Apakah ada argument-argumen yag dapat dipahami oleh manusia?

Sebagian ulama salaf dan khalâf menyatakan bahwa hukum syariah memiliki landasan-landasan argumentatif dan tujuan-tujuan tertentu. Tujuan-tujuan dan alasan serta hikmah dalam penetapan hukum Islam dapat dipahami secara rasional, global, dan terperinci dalam

al-Rahîm al-Mubarakfurî, Tuhfah al-Ahwadzî, (Bayrût: Dâr al-Fikr, 1424H-2003M), Jilid V, h. 426.

${ }^{33}$ Yûsuf al-Qaradhawî, Al-Hialal wa al- $\underline{H}$ arâm fi al-Islàm, h. 37.

${ }^{34}$ Imâm Abî Zakariyyâ Yahyâ ibn Syaraf al-Nawawî al-Dimasyqi,

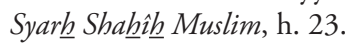

hukum-hukum yang bersifat kepatuhan (tảabbudî) karena mengandung rahasia-rahasia Allah. Hanya saja sebagian kecil ahli kalam dan ahli fikih, seperti Mazhab Zhâhiriyyah, menentang hal ini.

Dalam pandangan Hujjah al-Islâm Muhammad ibn Abû Hâmid al-Ghazâlî (w. 550H), bahwa segala sesuatu yang diharamkan adalah jelek atau kotor, hanya saja derajat kejelekan dan kekotorannya itu satu sama lain berbeda. Segala sesuatu yang halal itu baik, hanya saja derajat kebaikannya satu sama lainnya berbeda. Berdasarkan pada pandangan ini menurut alGhazalî seorang Mukmin dalam menyikapi hal yang dihalalkanpun diperlukan kearifan. Sejauhmana dampak makanan atau minuman yang dihalalkan bagi kualitas ketakwaan seseorang. ${ }^{35}$

Ketentuan Islam mengenai makan dan minum kategori halal, haram, dan syubhat, didasarkan pada Alquran dan Hadis.

Alquran ketika berbicara tentang beberapa jenis makanan yang diharamkan, dijelaskan sebab larangan tersebut, yaitu "fisq" sebagaimana tertera dalam Q.s. 5:3, 6: 121, dan 145. Kata tersebut secara etimologis berarti" keluar" atau "melampaui batas". Ulama mengaitkan keharaman makanan-makanan tertentu dengan dampak negatifnya pada mental manusia. Al-Biqầî (w. 1480M) dengan mengutip pendapat al- $\underline{\text { Harralî }}$ (w. $1232 \mathrm{M}$ ), berpendapat bahwa jenis daging dapat mempengaruhi sifat-sifat mental seseorang. Ia menyimpulkan hal itu antara lain dari penggunaan kata "rijs" yang diartikannya dengan "kejelekan budi pekerti” sebagaimana ditegaskan oleh Alquran dalam kaitannya dengan larangan makananmakanan dan minuman tertentu (Q.s. 5: 90, 6:145). Pendapat serupa dikemukan juga oleh ulama Muslim kontemporer, Syaikh Taqi Falsafi, dalam Child between Heredity and Education dengan mengutip pendapat Alexis Carrel yang menyatakan bahwa "pengaruh dari campuran kimiawi yang dikandung oleh makanan terhadap aktivitas jiwa dan pikiran, belum lagi diketahui secara sempurna".

\section{Tujuan Pengaturan Halal dan Haram}

Ulama menegaskan bahwa hukum Islam diciptakan untuk mewujudkan kemaslahatan manusia di dunia dan akirat. Kemaslahatan ada yang besifat primer (dharûriyyah), sekunder (hajiyyah), dan ada yang bersifat tersier (tahsiniyyah), sebagaimana dinyatakan Imam al-Ghazalî dan al-Syâthibî. Menurut Imam alSyâthibî, tugas syariah berorientasi pada terwjudnya tujuan-tujuan kemanusiaan yang terdiri atas bagian

${ }^{35}$ Muhammad ibn Muhammad Abû Hâmid al-Ghazalî, Mukhtashar Ihyyâ' 'Ulûm al-Dîn, (Bayrût: Dâr al-Fikr, 1406H-1986M), h. 102. 
primer (dharûriyyah), sekunder (hajiyyah), dan tersier (tabsiniyyah). Primer, artinya sesuatu yang harus ada guna terwujudnya kemaslahatan agama dan dunia. Apabila sesuatu itu hilang, kemaslahaan manusia akan sulit terwujud, bahkan akan menimbulkan kerusakan, kekacauan dan kehancuran.

Di sisi lain, kebahagiaan dan kenikmatan akan lenyap dan kerugian yang nyata akan muncul. Untuk menjaga hal tersebut diperlukan dua hal. Pertama, sesuatu yang dapat menjaga dan mengukuhkan pondasi dan kaidah syariat dan merupakan aspek utama untuk menjaga keberadaan syariat. Kedua, sesuatu yang dapat mencegah pelanggaran langsung atau tidak langsung terhadap syariat dan merupakan aspek untuk menghindari kepunahan syariat.

Imam al-Qarâfî menambahkan komponen ke enam, yaitu kehormatan yang sering disebut sebagai harga diri. Oleh karena itu syariat mengharamkan fitnah atau menuduh berzina (qadzaf), membicarakan aib orang lain (ghibah). Menurut Imam al-Syâthibî, kemaslahatan yang bersifat sekunder adalah segala hal yang dibutukan untuk memberikan kelonggaran dan mengurangi kesulitan yang biasanya menjadi kendala dalam mencapai tujuan. Adapun kemaslahatan yang bersifat keutamaan (tabsiniyyah) adalah melakukan tindakan yang lain menurut adat dan menjauhi perbuatan-perbuatan aib yang ditentang oleh akal sehat. Kemaslahatan ini merupakan keutamaan akhlak.

Apabilasyariatbertujuanuntukmenjagakemaslahatan, ini dapat dipahami bahwa syariat bertujuan mencegah dan menghilangkan kerusakan-kerusakan. Prinsip ini ditegaskan dalam Hadis "Tidak ada kemudaratan dan tidak boleh memudaratkan (لاضرر ولاضرار)". Hadis tersebut adalah Hadis $\hat{A} \underline{h} \hat{a} d$. Maksud Hadis ini "tidak ada kemudaratan dan tidak boleh memudaratkan", yaitu seseorang tidak boleh merusak dirinya dan orang lain. Tidak boleh memulai berbuat kerusakan atau membalas dengan kerusakan. Apabila kerusakan dan perbuatan merusak dilarang, kemaslahatan dan kesejahteraan akan terjaga dan terpelihara. Dari hadis ini, ada ulama berkesimpulan bahwa pada prinsipnya kemudaratan itu haram. Kata mudarat yang dimuat dalam Hadis tersebut berbentuk umum (nakirah) dalam ungkapan peniadaan (nafiy). Dengan demikian yang dimaksud mudarat yaitu pelbagai jenis kerusakan. Sedangkan kemaslahatan (manâfi) pada prinsipnya adalah mubah.

Imam Syâthibî mengisyaratkan bahwa pemeliharaan kemaslahatan atau tujuan- tujuan syariat dapat diwujudkan dalam dua bentuk, yaitu positif (ijâbiyyah) dan negatif (salabiyah). Positif dalam arti, syariat harus memelihara hal-hal yang dapat menegakkan dan mengukuhkan pilar-pilarnya dan dan negatif dalam arti, syariat mencegah pelanggaran langsung atau tidak langsung yang dapat merusaknya. Oleh karena itu mencegah kerusakan sangat diperlukan untuk menegakkan kemaslahatan.

\section{Makanan dan Minuman yang Diharamkan Bangkai}

Sesuai dengan Alquran surah al-Mầidah (5): 3, al-Baqarah (2): 172-173, al-Mầidah (5): 3, dan alAn'âm (6): 145. Imam al-Syawkânî mendefinisikan bangkai sebagai binatang yang mati dengan sedirinya, atau dengan kata lain, kematiannya tidak disebabkan karena perbuatan manusia, dengan sengaja disembelih atau karena diburu. Binatang yang kematiannya tanpa penyembelihan secara syariat. Jadi bangkai adalah hewan yang mati dengan sendirinya atau hewan yang kematiannya tanpa disembelih secara syar'i.

Dikecualikan dari bangkai dua hal, yaitu bangkai belalang dan bangkai ikan laut berdasarkan Hadis yang bersumber dari Ibn Amr secara marfû́ yang diriwayatkan Ahmad, Ibn Mâjah, al-Dâr Quthnî, Hakim, dan Ibn Mardawiyah:

$$
\text { [أحل لنا ميتتان ودمان] وأخرجه أحمد وابن ماجه }
$$

Al-Sa'dî menyatakan keumuman ayat ini (bangkai) ini dikecualikan secara syar'i oleh Hadis yang menyatakan kehalalan bangkai, yaitu bangkai belalang dan bangkai ikan. Hadis yang menjadi pegangan adalah:

$$
\begin{aligned}
& \text { بقوله عليه السلام: [أحلت لنا ميتتان الحوت والجراد }
\end{aligned}
$$

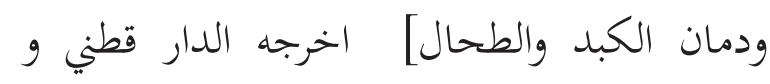

$$
\begin{aligned}
& \text { كذلك حديث جابر في العنبر يخصص عموم القرآن } \\
& \text { بصحة سنده خرجه البخاري و مسلم }
\end{aligned}
$$

Tentang tujuan pengharaman bangkai dari jenis yang telah disebutkan, menurut Ibn Katsîr pengharaman makan bangkai tidak lain karena pada bangkai terdapat kemudaratan bahaya yaitu darah yang tertahan, tentu ini sangat membahayakan bagi agama dan tubuh, oleh karenanya Allah mengharamkannya. ${ }^{36}$ Yûsuf al-Qaradhawî mencatat lima hikmah dari diharamkannya bangkai.

Pertama, fitrah yang sehat menetapkan bahwa ia adalah kotor. Akal pikiran yang normal mengatakan bahwa makan bangkai merendahkan derajat manusia. Kedua, seseorang Muslim dibiasakan untuk memiliki maksud dan niat dalam setiap urusannya. Ia tidak memperoleh se-

${ }^{36}$ Abî al-Fidâ al-Hâafizh ibn Katsîr al-Dimasyqî, Tafsîr al-Qur'ân al-Azhîm, h. 11. 
suatu kecuali setelah memantapkan niat dan kehendaknya untuk itu. Ketiga, binatang yang mati dengan sendirinya, kemungkinan besar disebabkan karena umurnya sudah tua, atau kecelakaan, atau memakan tumbuhan yang beracun, atau musibah lainnya. Semua itu tidak dapat dijamin keamanannya. Keempat, dengan pengharaman bangkai itu atas kita maka Allah hendak memberi kesempatan kepada binatang untuk kita santap, sebagai wujud kasih sayang Allah padanya, karena mereka juga umat sebagaimana kita. Kelima, agar manusia memelihara binatang yang menjadi miliknya, tidak dibiarkan begitu saja ia sakit, melemah, lalu mati sia-sia. ${ }^{37}$

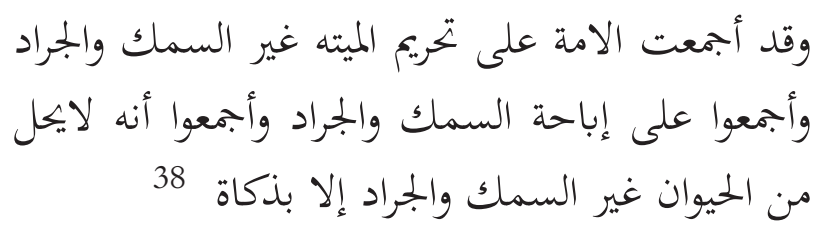

\section{Darab}

Ayat-ayat alquran yang menetapkan keharaman darah adalah al-Baqarah (2): 172-173, al-Mầidah (5): 3. Penjelasan mengenai hukumnya darah ditemukan dalam kitab-kitab tafsir dan fikih. Al-Thabarî menegaskan bahwa yang dimaksud dengan darah yang diharamkan adalah berkaitan dengan darah yang mengalir " "ادم المسفوح", adapun darah yang tidak mengalir, maka tidak haram berdasarkan ijmak ulama, dengan merujuk firman Allah pada surah al-

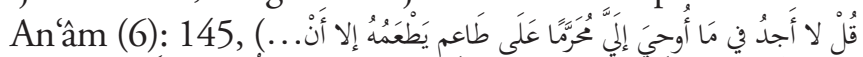

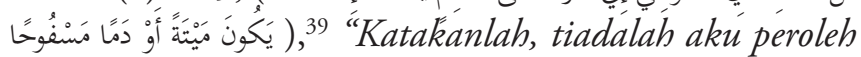
dalam wahyu yang diwahyukan kepadaku, sesuatu yang diharamkan bagi orang yang hendak memakannya, kecuali kalau makanan itu bangkai, atau darah yang mengalir atau daging babi, karena sesungguhnya semua itu kotor-atau hewan yang disembelih atas nama selain Allah."(Al-An'âm [6]: 145). Al-Thabarî berkesimpulan, ayat tersebut merupakan dalil yang jelas bahwa darah yang tidak mengalir adalah halal dan tidak najis. ${ }^{40}$

Abû Bakr Ibn al-'Arabî (1076-1148 M/468-543H) menegaskan bahwa ulama telah sepakat (ijmak) mengenai hukum darah, yaitu haram dan najis tidak boleh dikonsumsi dan dimanfaatkan. ${ }^{41}$ Pendapat yang serupa juga dikemukakan oleh al-Qurthubî. Hal ini menurut al-Qurthubi telah menjadi ijmak ulama.

Untuk lebih memahami alasan bahwa darah yang

\footnotetext{
${ }^{37}$ Yûsuf al-Qaradhawî, Al-Halâl wa al-Harâm fi al-Islâm, h. 75.

${ }^{38}$ Imâm Abî Zakariyyâ Yahyâ ibn Syaraf al-Nawawî al-Dimasyqi, Syarh Shahîh Muslim, h. 72.

${ }^{39}$ Muhammad ibn Jarîr ibn Yazîd ibn Katsîr ibn Ghâlib al-Amalî Abû Ja'far al-Thabari, Jami' al-Bayân fi Táwil al-Qur'ân, h. 492.

${ }^{40}$ Muhammad ibn Jarîr ibn Yazîd ibn Katsîr ibn Ghâlib al-Amalî Abû Ja'far al-Thabari, Jami' al-Bayân fi Tảwil al-Qur'ân, h. 193.

${ }^{41}$ Abû Bakr Muhammad ibn 'Abd Allâh Ibn al-'Arabî, A $\underline{h} k \hat{a} m$ alQur'ân, (Bayrût: Dâr al-Fikr, t.th), h. 78.
}

diharamkan adalah darah yang mengalir, Aḥmad al-Râzî al-Jashshâsh (917-980 M/305-370H) dalam Ahkâm alQur'ân menggambarkan andaikan tidak ada ayat yang menetapkan haramnya darah selain ayat pada surah

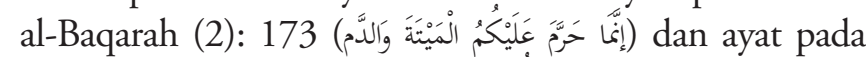

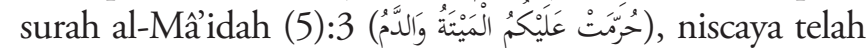
berlakulah ketetapan haramnya darah secara keseluruhan, baik sedikit maupun banyak. Tetapi kemudian Allah berfirman pada ayat lain dalam surah al-An'âm (6):145,

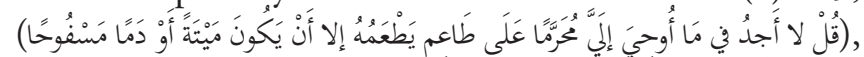
maka ayat tersebut sebagai dasar (dalil) yang ménegaskan bahwa darah yang diharamkan adalah darah yang mengalir bukan selainnya. Adapun Âtsâr yang menjadi dasar memperkuat yaitu berasal dari Ikrimah yang

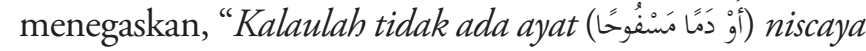
kaum Muslimin akan mengikuti hukum tulang yang sedikit dagingnya sebagai orang-orang Yahudi mengikutinya." Terdapat juga Atsâr Qatâdah yang menjelaskan ayat (مَو (دمَاً مَسْفُونًا (a) ia menuturkan, "Yang diharamkan pada darah adalah yang mengalir, adapun daging yang bercampur dengan darah maka tidak mengapa (halal)". Ditambahkan oleh al-Jashshash, berdasarkan riwayat al-Qâsim ibn Muhammad dari 'Â'isyah telah ditanyakan mengenai darah yang terdapat pada daging dan sembelihan, maka ia menjawab, "Sesungguhnya Allah melarang darah yang mengalir". Al-Jashshâsh menegaskan tidak ada perbedaan pendapat para fukaha mengenai bolehnya mengonsumsi daging yang masih ada tersisa darah pada tulang yang sedikit dagingnya, karena darah tersebut tidak mengalir ${ }^{42}$. Menurut al-Jashshâsh, fukaha mazhab Hanafi berpendapat, darah ikan tidaklah najis, karenanya boleh dimakan beserta darahnya. Adapun mengenai darah udang, menurut pendapat Imam Malik sebagaimana dikutip oleh al-Jashshash, apabila telah menjadi kotor agar dicuci, demikian pula dengan darah lalat dan darah ikan dicuci.

Al-Syawkânî memberikan rincian bahwa ayat-ayat (al-Baqarah (2): 172-173, al-Mầidah (5): 3)—yang menetapkan keharaman darah bersifat mutlakpemahaman ayat-ayat tersebut dibatasi (المقيد) dengan ayat lainnya surah al-An'âm (6):145. Dengan demikian, darah yang diharamkan adalah darah yang mengalir. ${ }^{43}$ Pendapat al-Syawkânî tersebut sejalan dengan pandangan Abû Bakr Ibn al-'Arabî. Menurut dia, kalau pada al-Baqarah (2) 173 Allah menetapkan darah secara mutlak (مطلقا), kemudian ditentukan pada surah al-An'âm (6):145 dibatasi atau diikat dengan darah yang mengalir, oleh karena para ulama memahami ayat

${ }^{42}$ Abû Bakr Ahmad al-Râzî al-Jashshâsh, A $\underline{h} k a ̂ m$ al-Qur'ân, (Bayrût: Dâr al-Fikr, 1414H/1993M), jilid I, h. 173

${ }^{43}$ Muhammad al-Syawkânî, Fath al-Qâdir al-Jami' bayn Fann alRiwâyah wa al-Dirâyah min 'Ilm al-Tafsîr; Lihat juga 'Abd al-Rahmân ibn Nashir ibn al-Sa'di, Taysîr al-Karîm al-Rahmân. 
dengan membawanya kepada arti atau makna yang dibatasi secara ijmak. Dan hal ini telah dikuatkan Hadis riwayat 'Aisyah,"Andaikan Allah tidak berfiman “ (حَمًا مَسْفُحًا darah yang terdapat pada tulang, maka janganlah kalian berpaling mengenai masalah itu kepada yang diasalkan kepada Ibnu Mas'ud mengenai masalah darah". ${ }^{44}$

Tentang darah, al-Qurthubî menambahkan sebagaimana telah menjadi kesepakatan ulama mengenai haramnya darah, maka menurut dia, darah hukumnya haram dan najis, juga tidak boleh dikonsumi dan dimanfaatkan. Kemudian al-Qurthubî menulis pandangan Ibn Huwayz Mandad, bahwa darah yang diharamkan selama kesulitannya tidak meliputi, dan dapat dimaafkan karena kesulitannya yang meliputi secara umum, seperti darah yang terdapat pada daging atau yang terkena pada pakaian dan digunakan untuk salat, dengan alasan bahwa ketentuan ayat yang mengharamkan darah, yaitu al-Baqarah (2): 173 dikaitkan dengan al-An'âm (6):145, dengan demikian menunjukkan darah yang diharamkan adalah darah yang mengalir. Kedua, dasarnya Hadis 'Â' 'isyah:

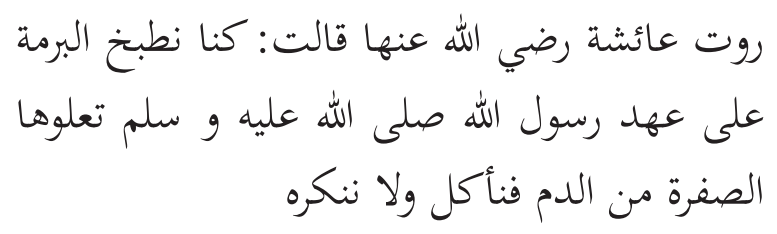

Telah diriwayatkan dari 'Â'isyah R.a. pernah memasak daging, sehingga warna kuning dari daging meluap pada bejana yang terbuat dari tanah, pada masa Rasulullah Saw., kami bersama mengonsumsinya dan kami tidak mengingkarinya.

Menurut dia, menjaga diri darinya adalah merupakan beban dan sulit, sementara beban dan kesulitan dalam agama diletakkan dan ini adalah asas agama Islam, sebagaimana halnya ketika umat ini mengalami kesulitan dalam melaksanakan ibadah dan dirasakan berat melakukannya, maka menjadi gugurlah ibadah itu, seperti halnya seseorang yang dalam keadaan terpaksa maka ia dibolehkan mengonsumsi bangkai. ${ }^{45}$

Abû Bakr Muhammad ibn 'Abd Allâh Ibn al-'Arabî memberikan tanggapan terhadap alasan ulama yang berpendapat bahwa ayat yang mengharamkan darah (al-Baqarah (2):73 dan al-Mầidah (5):3) dibatasi dengan surah al-An'âm (6):145. Menurut dia, jika ada pendapat bahwa firman Allah pada surah al-An'âm (6): 145 (خَوْ دَمًا مَسْفُوحًا) adalah khusus (خاص) berkenaan dengan sifat tersebut, sedangkan firman Allah

${ }^{44}$ Abû Bakr Muhamamad ibn 'Abd Allâh Ibn al-'Arabî, A $\underline{h k a ̂ m}$ alQur'an, jilid I, h.79.

${ }^{45}$ Lihat: Abû 'Abd Allâh Muhammad Ahmad al-Anshârî alQurthûbî, Al-Jâmi' li Abkâm al-Qur'an. pada kedua surah lainnya adalah umum mencakup seluruh darah, maka tentu wajib melaksanakan pada keumuman ayatnya, karena tidak terdapat pada ayat yang mengkhususkannya. Maka dikatakan kepadanya

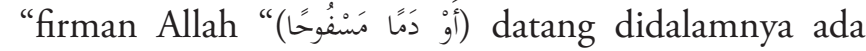
peniadaan/penyangkalan keharaman seluruh darah terkecuali yang mencakup sifat tersebut. Karena firman

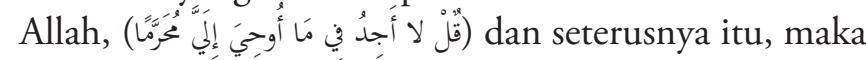
yang demikian itu adalah sesuai dengan seperti kami telah sifati, maka tidaklah maksudnya dari firman Allah al-Baqarah (2) 173 datang kemudian setelah firman Allah pada surah al-An'âm (6):145 atau keduanya turun secara bersamaan. Namun, ketika tidak ada pada kita sejarah/catatan waktu turunnya kedua ayat dimaksud, maka wajib menetapkan bahwa keduanya turun bersamaan, maka pada saat itu tidak dapat ditetapkan keharaman darah terkecuali dihubungkan dengan sifat tersebut yaitu darah yang mengalir.

Pada bagian lain, Abû Bakr Ibn al-Arabî mencatat perbedaan pandangan ulama mengenai kekhususan keumuman ayat tersebut dengan hati dan limpa. Satu pendapat menyatakan tidak ada kekhususan (تحصيص) pada ayat tersebut. Ini adalah pendapat Imam Malik. Sementara Imam al-Syâfîi berpendapat bahwa ayat tersebut dikhususkan. Pendapat yang benar menurut Ibn al-Arabî adalah bahwa ayat tersebut tidak dikhususkan, karena menurut dia hati dan limpa adalah daging sebagaimana disaksikan dengan melihatnya dengan mata sendiri yang tidak memerlukan lagi pejelasan.

Dalam Ahkâm al-Qur'an Ibn al-'Arabîi ${ }^{46}$ menyatakan, "Para ulama berselisih pendapat mengenai darah yang dikategorikan termasuk haram, di antaranya ada dua pendapat. Golongan pertama mengatakan bahwa memakan segala macam darah adalah haram kecuali hati dan limpa sebagaimana yang diprioritaskan Sunah. Pendapat kedua menyebutkan bahwa pengharaman ini khusus berlaku pada darah yang mengalir, dengan dasar apa yang dikatakan oleh 'Â'isyah dan Ikrimah serta Qatâdah. Diriwayatkan dari 'Â'isyah, ia berkata, "Kalaulah Allah Swt. tidak berfirman demikian, "atau darah yang mengalir (al-An'âm:145), niscaya orangorang akan menganggapnya seperti darah yang melekat pada tulang".

Imam al-Hafiz mengambil jalan tengah dengan berpendapat bahwa yang tepat adalah bahwa apabila darah itu berada tersendiri maka haram dimakan, dan jika bercampur dengan daging maka boleh dimakan, karena bila bercampur dengan daging tidak mungkin untuk dipisahkan. Pengharaman yang dimaksud dalam ayat

${ }^{46}$ Abû Bakr Muhammad ibn 'Abd Allâh Ibn al-'Arabî, A $\underline{h} k \hat{a} m$ alQur'ân, h. 756. 
adalah karena kondisi darah yang sudah menyendiri.

Dalam fikih mazhab Maliki diterangkan bahwasanya darah hewan yang tidak boleh dimakan adalah haram, baik sedikit maupun banyak. Darah hewan yang halal dimakan, apabila masih hidup maka hukumnya haram. Alasan pengharaman pada darah hewan yang halal adalah karena termasuk ketegori darah yang mengalir. ${ }^{47}$

Hati dan limpa /paru-paru adalah termasuk jenis darah, akan tetapi hukumnya halal untuk dimakan, dengan dasar hadits Nabi saw. Dan sekiranya tidak ada nash dari hadits tersebut niscaya tidak halal karena keduanya adalah darah dan hukum asal dari darah adalah haram. ${ }^{48}$

Mengalirnya darah adalah syarat yang menjadi pengharamannya, yaitu darah mengalir dari hewan yang boleh disembelih. Maksudnya adalah darah yang mengalir di saat atau seusai penyembelihan hewan yang halal untuk disembelih. Sedangkan darah yang mengalir dari hewan yang masih hidup maka sedikit atau banyaknya haram. Demikian pula darah hewan yang haram dimakan, meskipun disembelih, sedikit atau banyak hukumnya haram secara mutlak. ${ }^{49}$

\section{Babi}

Dasar yang mengharamkan daging babi adalah Alquran surah al-Baqarah (2): 173, al-Mầidah (5): 3, al-An'âm (6): 145, dan al-Nahl (16): 115. Dalam

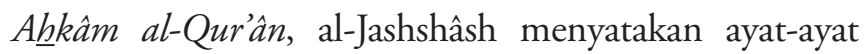
tersebut secara jelas menegaskan keharaman daging babi. Memang dalam ayat-ayat tersebut sekalipun yang disebut secara khusus adalah daging babi, namun demikian yang dimaksud adalah seluruh bagian babi, karena dagingnya yang paling besar manfaat dan yang dikehendaki. AlJashshâsh mendasarkan pendapatnya ini bahwa akan halnya Allah menentukan keharaman membunuh binatang buruan bagi seorang yang sedang ihram, maka maksud larangan atau pecegahan tersebut tentunya adalah larangan atau pencegahan seluruh perbuatan perburuan. Adapun disebutkannya membunuh buruan secara khusus karena membunuh bintang buruan merupakan tujuan terbesar dalam perburuan.

Ditambahkan pula oleh al-Jashshâsh ayat-ayat yang serupa dengan ini cukup banyak..$^{50}$ Maka demikian

\footnotetext{
${ }^{47}$ Abû al-Qâsim Muhammad ibn Ahmad ibn Juza’i al-Kalabî, $A l$ Qawânîn al-Fiqhiyyah, (Dâr Ibn Hazm, 1997), h. 150.

${ }^{48}$ Lihat Ensiklopedi Hukum Islam, h. 164-167.

${ }^{49}$ Ibn Rusyd, Bidayah al-Mujtahid, jilid I, h. 488.

50 Misalnya larangan berjualan setelah diselenggarakan azan sebagaimana terdapat pada surah al-Jumu'ah ayat 9. Dalam ayat tersebut penentuan larangan berjualan secara khusus, karena jual beli merupakan aktivitas terbesar yang dituju dari sekian manfaat berjual beli, pada hal yang yang dimaksud sebenarnya adalah mencakup
}

juga disebutkannya larangan daging babi secara khusus merupakan penguatan terhadap keharaman daging babi dan larangan terhadap seluruh bagiannya sehingga jelaslah bahwa yang dimaksud adalah larangan terhadap keseluruhan babi sekalipun yang yang ditegaskan secara jelas khusus mengenai dagingnya. ${ }^{51}$ Pendapat yang senada juga ditegaskan oleh al-Syawkânî bahwa tekstual (zahir) ayat-ayat pengharaman babi menegaskan bahwa yang diharamkan adalah dagingnya saja. Al-Sawkânî menegaskan bahwa umat telah sepakat mengenai keharaman lemak babi sebagaimana disampaikan oleh alQurthubî. ${ }^{52}$

Dalam kaitannya dengan pengharaman daging babi, Ahmad H. Sakr berdasarkan ayat-ayat pengharaman babi yang terdapat pada empat surah sebagaimana telah disebutkan, dapat dikatakan bahwa babi diharamkan secara keseluruhannya di dalam Islam bagi seorang Muslim dan juga kepada non-Muslim. Alasannya, karena firman Allah dalam surah al-An'âm (6): 45, yaitu adalah jelas bahwa larangan mengonsumsi babi adalah berlaku setiap orang. ${ }^{53}$

Ulama sepakat bahwa babi mutlak haram secara keseluruhan. Dalam buku Maratib al-Ijma', Ibnu Hazm menyebutkan bahwa para ulama sepakat bahwa, baik jantan maupun betina dan kecil maupun besar, hukumnya haram. Haram dagingnya, syarafnya, otaknya, tulang rawannya, isi perut (usus), kulitnya, dan anggota tubuh lainnya. ${ }^{54}$ Maka tidak diperkenankan makan sebagian dari salah satu bagian tubuh babi, baik yang berupa daging, kulit, lemak dan anggota tubuh lainnya. Hal ini sudah disepakati oleh semua umat Islam. ${ }^{55}$

Tidak ada satu pun ulama yang membolehkan memakan babi baik daging maupun lemaknya. Seperti yang dituduhkan kepada sebagian pendapat Zâhiriyyah, padahal mereka sendiri melalui Ibn $\underline{\text { Hazm }}$ telah berpendapat bahwa babi secara mutlak hukumnya haram. Tidak ada sebagian kecil pun dari babi yang halal baik bulu atau bagian lainnya.

seluruh aktivitas yang dapat melalaikan salat Jumat. Maka penyebutan jual beli secara khusus merupakan penguatan larangan jual beli yang dapat menyibukkan dari salat. Demikian juga halnya dengan daging babi, pelarangannya disebutkan secara khusus adalah sebagai penguat hukum keharaman daging babi dan pencegahan seluruh bagiannya.

${ }^{51}$ Abû Bakr Ahmad al-Râzî al-Jashshash, A $\underline{h k a ̂ m}$ al-Qur'ân, (Bayrût: Dâr al-Fikr, 1414 H-1993M), Jilid I, h. 173.

${ }^{52}$ Lihat al-Syawkânî, Fath al-Qâdir.

${ }^{5}$ Ahmad H. Sakr, Understanding Halal Foods Fallacies \& facts, (Lombard: Foundation For Islamic knowledge, 1996); Lihat juga Imam al- Jashshsash jilid I, h. 174.

54 Ibn Hazm al-Andalûsî, Marâtib al-Ijmầ, (Dâr al-Âfâq alJadîdah, t.th), h. 148.

${ }^{5}$ Bidâyah al-Mujtahid, jilid I, h. 488; al-Qawânîn al-Fiqhiyyah, h. 34; al-Mughnî, Jilid I, h. 136; Mughni al-Mubtâj, Jilid I, h. 77; Syarh al-Minhâj, Jilid I, h. 69. 
Mengapa diharamkan? Ia adalah hewan kotor, karena salah satu makanan yang paling ia sukai adalah kotoran dan benda-benda najis. Ia adalah hewan yang berbahaya di semua tempat dan benua, terutama di daerah-daerah yang bercuaca panas, sebagaimana dijelaskan dalam sebuah penelitian. Memakan daging babi akan menyebabkan penyakit cacingan yang bisa menyebabkan kematian. Lebih dari itu memakan daging babi akan mempengaruhi sifat kesucian dan kemuliaan seseorang. ${ }^{56}$ Oleh karena itu, baik daging maupun seluruh angota tubuhnya termasuk cairan-cairannya hukumnya haram tidak boleh dijadikan menu makanan atau gizi.

\section{Penyembelihan untuk Selain Allah}

Dasar yang mengharamkan penyembelihan untuk selain Allah terdapat pada surah al-Baqarah (2): 173, al-Mâiidah (5): 3 dan al-An'âm (6): 145. Menurut alThabârî alasan disebut dengan "وما أهلَ به" (14) karena orangorang Jahiliah apabila akan menyembelih sesuatu yang dapat mendekatkan mereka kepada sembahannya (tuhannya), mereka menyebutnya dengan nama tuhan mereka yang mereka tuju untuk mendekatkannya, pada saat penyembelian mereka mengeraskan suaranya, suara mereka yang tinggi ketika melakukan penyembelihan itulah yang disebut sebagai "الإهلال," Qurthubî berarti mengangkat suara. ${ }^{58}$ Adapun yang dimaksud dengan firman Allah dalam surah al-Mầidah: 3, yaitu وما أهل لغير الله به , menurut al-Thabârî, yaitu hewan yang disembelih untuk sesembahan (tuhan) mereka atau untuk patung, pada sembelihannya disebutkan nama selain Allah. Jadi apa beda kedua surah itu? AlHâfizh Ibn Katsîr menegaskan bahwa hewan yang ketika disembelih disebut atas nama selain Allah adalah haram, alasannya karena Allah telah mewajibkan setiap makhluknya agar disembelih atas nama-Nya (Allah) yang agung maka menyimpang dari ketentuan ini dan pada penyembelihannya disebutkan selain nama (asma)-Nya, seperti patung atau thaghut atau selainnya dari seluruh makhluk, maka hukumnya haram secara ijmak. ${ }^{59}$

Apa perbedaan uhilla bih li ghayrillâh dengan uhilla li ghayrillah bih? Asal pengertian al-Ihlâl menurut Muhammad 'Alî al-Sayis yaitu mengangkat suara dan menjelaskannya/mengeraskannya. Oleh karena itu sebagaimana dikatakan al-Malba mengenai haji/umrah Umar R.a, Ihlâl yaitu mengangkat suaranya dengan

${ }^{56}$ Imam 'Alî al-Sayis, Tafsir Âât al-A $\underline{h} k \hat{a} m$, Jilid, 1 h. 79; Ibn Katsir, h. 251

${ }^{57}$ Abû Ja'far Muhammad ibn Jarîr al-Thabârî, Tafsîr al-Thabârî, maktabah syamilah, h. 492.

${ }^{58}$ Abû 'Abd Allâh Muhammad Ahmad al-Anshârî al-Qurthûbî, $A l$ Jâmi' li Alhkâm al-Qur'an, Jilid I, h. 210.

${ }^{59}$ Ibn Katsir, Jiilid II, h. 11. mengucapkan talbiyah. Pendapat lain menyebutkan, bayi menangis dengan suara keras, jika berteriak pada kelahirnnya, adalah bangsa Arab apabila mereka akan melakukan penyembelihan bisa dengan mendekatkan sembelihannya dengan patungnya dan mereka menyebutnya dengan nama patung mereka dengan mengangkat suaranya. Adapun makan "uhilla bih li ghayrillah" yaitu sesuatu yang disembelih untuk selain Allah. ${ }^{60}$

Menurut Kamil Musa artinya mengangkat suara. Misalnya anak kecil yang baru dilahirkan menjerit dan menangis disebut ihlâl. Sedangkan yang dimaksud di sini adalah hewan yang disembelih dengan menyebutkan selain nama Allah Swt. seperti seorang beragama Pagan menyembelih dengan menyebut Lata dan Uza. Orang Majusi menyembelih dengan menyebutkan api dan orang Nasrani menyebutkan nama al-Masih. Sedangkan Yahudi menyebut nama Uzair ketika hendak menyembelih hewan. Ini adalah perumpamaan bukan pembatasan. Artinya masih banyak lagi contoh orang menyembelih dengan tidak menyebutkan nama selain Allah, misalnya menyebutkan orang mati. Hal ini termasuk hewan yang disembelih dengan menyebut selain nama Allah. ${ }^{61}$

Ibn Nâjim, seorang pakar fikih Islam aliran Hanafiah sebagaimana dikutip oleh Kamil Musa. Menurut dia sudah jelas dalam bahwasanya sembelihan untuk orang yang pulang dari haji dan pulang perang atau pemimpin dan sebagainya membuat hewan yang disembelihnya sama hukumnya dengan bangkai. ${ }^{62}$ Dari penjelasan di atas tampak jelas bahwa niat penyembelihan harus diperuntukkan kepada Allah bukan untuk makhluk atau untuk kepentingan sesuatu lainnya.

Al-Thabârî, dengan mengutip pendapat Abû Ja'far bahwa para ahli takwil berbeda pendapat mengenai sifat (الانخناق), al-Sudi berpendapat al-Munkhaniqah adalah hewan yang kepalanya antar dua dahan (syu'bah) pada suatu pohon lalu mati, maka tercekik kemudian mati. Al-Dhakah adalah hewan yang tercekik kemudian mati. Sedangkan Qatâdah memahami almunkhaniqah adalah hewan yang mati karena tercekik tali yang terdapat pada lehernya. Menjadi tradisi orangorang Jahiliah mereka (yakhnaquna) kambing mereka sehingga mati, kemudian mereka mengonsumsinya, maka Allah mengharamkannya. ${ }^{63}$ Menurut al-Thabârî dari pendapat-pendapat tersebut adalah pendapat yang menyebutkan "hewan yang takhnaq, baik disebabkan

\footnotetext{
${ }^{60}$ Muhammad 'Alî al-Sayis, Tafsî̀ Âyât Ahkkâm, h. 14.

${ }_{61}$ Suyatno, Ensiklopedi Halal dan Haram dalam Makanan dan Minuman, (Surakarta: Ziyad Visi Media, 2006), h. 66.

${ }^{62} \mathrm{Ibid}$.

${ }^{63}$ Abû Ja'far Muhammad ibn Jarîr al-Thabârî, Tafsîr al-Thabârî, maktabah syamilah, h. 494.
} 
karena watsaq-nya, atau karena kepalanya masuk pada suatu tempat yang tidak bisa keluar darinya lalu tercekik kemudian mati. Alasan kami memilih takwil yang demikian karena karena " "لمنخنقة", ${ }^{64}$ bukan karena khanaq selainnya, berpendapat demikian, karena jika makna seperti itu maka itu berbentuk mafúul, niscaya disebut “والمخنوقة", sehingga hal itu memiliki arti seperti yang mereka utarakan.

\section{Al-Mawqûdzab}

Asal kata al-wâqidz konotasinya adalah sebuah pukulan yang keras. Adat semacam ini sering dilakukan oleh bangsa jahiliah. Mereka memukul binatang ternaknya dengan kayu hingga mati untuk dipersembahkan kepada tuhan-tuhan mereka, lalu mereka membuatnya sebagai jamuan. Yaitu hewan yang dipukul dengan batu atau tongkat hingga menyebabkan dia mati tanpa melalui proses penyembelihan. ${ }^{65}$

Menurut pendapat Ibn Abbas " adalah tradisi orang-orang jahiliah mereka memukul hewanya dengan tongkat sehingga mati, lalu mereka mengonsumsinya. Qatâdah menjelaskan, orang-orang jahiliah mereka memukul hewannya sehingga yaqdzuha, kemudian mereka mengonsumsinya. Tetapi menurut al-Dahak "والموقوذة" yaitu hewan yang dipukul lalu mati. Al-Sudi berpendapat yang sama. Al-Dhahak menambahkan adalah kambing atau hewan lainnya dari binatang ternak dipukul dengan kayu untuk tuhan (sesembahan) mereka, sehingga mereka membunuhnya kemudian mati lalu mereka mengonsumsinya. ${ }^{66}$

\section{Al-Mutaraddiyab}

Hewan yang terlempar dari tempat yang tinggi sehingga menyebabkan dia mati, baik jatuh dari gunung, sumur, lubang, atau tempat lainnya. AlTarada berasal dari kata radda yag berarti binasa. Baik terlempar dengan sendirinya maupun terlempar oleh orang lain. ${ }^{67} \mathrm{Ibn}$ 'Abbas " "والمتر ية" hewan yang tataradda dari atas gunung. Qatâdah mengartikan tataradda di dalam sumur, lalu mereka mengonsumsinya.

\section{Al-Nathîhah}

Al-Natihah yang berarti sesuatu yang menjadi

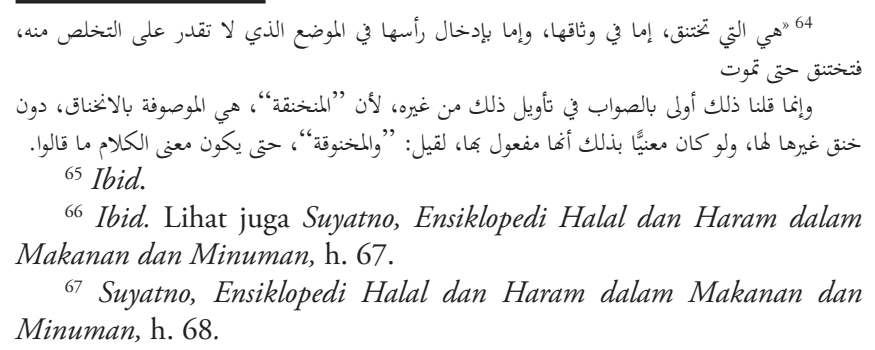

${ }^{66}$ Ibid. Lihat juga Suyatno, Ensiklopedi Halal dan Haram dalam Makanan dan Minuman, h. 67.

${ }^{67}$ Suyatno, Ensiklopedi Halal dan Haram dalam Makanan dan Minuman, h. 68.

korban. Yaitu hewan yang tertimpa oleh hewan lain dan menyebabkan mati tanpa proses penyembelihan

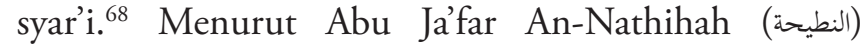
adalah kambing yang ditanduk oleh kambing lainnya, kemudian mati mati karena tandukan tanpa disembelih. Asli kata "“النطيحة" adalah " “منطوحة."

\section{Al-Sabu'u}

Yaitu hewan yang dimakan oleh binatang buas. Binatang yang bertaring seperti singa atau harimau. Atau dimangsa burung yang mempunyai kuku yang panjang dan tajam seperti elang dan garuda. Yang dimaksud di sini adalah hewan yang sebagian anggota tubuhnya sudah dimakan oleh binatang buas. Karena masyarakat Arab tidak menyukai binatang buas, jadi tidak mungkin mereka mau memakan sebagian sisa makanan mereka tanpa disembelih dengan cara syari, tetapi jika hewan yang diterkam oleh binatang buas tadi masih hidup dan masih sempat disembelih dengan penyembelihan secara syar'i maka hukumnya halal dan boleh dikonsumsi, sebagaimana disebutkan dalam sebuah Ayat: الَّ ما ذ كيتم ("Kecuali yang telah kalian sembelih").

\section{Al-Nusub}

Al-Nasb adalah batu yang didirikan di sekitar Kakbah mereka menyembelih binatang di atas batu tersebut untuk pengorbanan dan pendekatan diri kepada tuhannya. Sebagian orang menyebutkan bahwa nasb adalah berhala. Konon, bangsa Arab senang menyembelih hewan di Mekah, kemudian menyiramkan darahnya kepada sesuatu yang menghadap Kakbah. Mereka mengiris dagingnya dan meletakkannya di atas batu. Maka ketika Islam datang, orang-orang Muslim berkata kepada Nabi Saw., "Kami lebih berhak untuk memuliakan Kakbah ini dengan batu (al-nasb), maka kemudian Allah Swt. menurunkan ayat, "Wa mâ dzubih 'ala al-nusub." ${ }^{69}$

\section{Tanggung Jawab Produk ${ }^{70}$ Produsen dalam Produk Halal.}

Guidelines for Consumer Protection of 1985, yang dikeluarkan oleh Persatuan Bangsa-Bangsa (PBB) menyatakan, "Konsumen di manapun mereka berada, di

\footnotetext{
${ }^{68}$ Suyatno, Ensiklopedi Halal dan Haram dalam Makanan dan Minuman, h. 69.

${ }^{69}$ Lihat Ibn Katsir, Jilid II, h. 8; Tafsir al-Syawkani, Jilid I, h. 169, Jilid II, h. 8.

${ }^{70}$ Istilah product liability (tanggung jawab produk) memang baru dikenal sekira 60 tahun yang lalu dalam dunia perusuransian di Amerika Serikat, sehubungan dengan dimulai produksi bahan makanan secara besarbesaran, baik di kalangan produsen (producer and manufacture) maupun penjual (seller, distibutor) mengasuransikan adanya risiko akibat prdukproduk yang cacat atau menimbulkan kerugian terhadap konsumen.
} 
segala bangsa, mempunyai hak-hak dasar sosialnya." Yang dimaksud dengan hak-hak dasar-dasar tersebut adalah hak untuk mendapatkan informasi yang jelas, benar, dan jujur, hak untuk mendapatkan ganti rugi, dan hak untuk mendapatkan kebutuhan dasar manusia. ${ }^{71}$

Permasalahannya yang timbul adalah tidak sedikit produsen makanan dan minuman tidak mematuhi standar jaminan halal yang telah ditetapkan antara lain beberapa produk makanan dan minuman, seperti susu, mie, snack diketahui bahwa produk-produk tersebut mengandung gelatin, shortening, lecithin, dan lemak yang kemungkinan berasal dari babi. Setiap produsen harus memenuhi kebutuhan dan hak konsumen, termasuk konsumen Muslim sebagai tangung jawab produsen untuk produk yang dibawanya ke dalam peredaran yang menimbulkan kerugian atau ketidak nyamanan konsumen.

Untuk dapat pemahaman yang jelas tentang tanggung jawab produk Henry Campbell Black mendefinisikan tanggung jawab produk (prod uct liability) adalah to the legal liability of manufactures and seller to compensate buyer, user, and even by standers, for damage or injuries because $e$ of defect in goods purchase. Jadi yang dimaksud dengan tanggung jawab produk (product liability) adalah suatu tanggung jawab secara hukum dari produsen atau dari seorang sebagai kompensasi kepada konsumen yang tidak sesuai dengan standar karena cacat atau mengakibatkan kecelakaan terhadap produk yang dijual atau diedarkan. ${ }^{72}$

Menurut Natalie O'Connor, "product liability, these were designed to protect the consumer from faulty or defective goods by imposing strict liability upon manufactures." 73 Dari pendapat tersebut, tampak secara umum Natalie ingin menekankan pentingnya tanggung jawab produk untuk melindungi konsumen dari produk yang cacat atau barang-barang yang tertolak dengan penekanan yang strik kepada produsen.

Hukum tentang tanggung jawab produk ini termasuk dalam perbuatan melanggar hukum, diimbuhi dengan tanggung jawab mutlak (strict liability), tanpa melihat apakah ada unsur kesalahan pada pihak pelaku. ${ }^{74}$ Dalam terminologi ilmu hukum tanggung

\footnotetext{
${ }^{71}$ Az. Nasution, Hukum Perlindungan Konsumen Suatu Pengantar, (Yogjakarta: Diadit Media, 2001), h. viii.

72 Adrian Sutedi dalam Henry Campbell Black, Black Law Dictionary, Sixth Edition, (St. Paul Minnesota: West Publishin Company, 1983), h. 840.

${ }^{73}$ Adrian Sutedi dalam Ray H. Anderson, "Current Problem in Product Liability Law and Product Liability Insurance", Insurance Counsel Journal, July, 1964, h. 445.

74 Ketentuan yang mengatur hal tersebut, yaitu perbuatanperbuatan pelaku usaha yang berakibat menimbulkan kerugian dan/ atau membahayaan konsumen diatur dalam Pasal 4, 5, 7-17, 1921 dan Pasal 24 sampai dengan Pasal UU No. Tahun 1989 tentang Perlindungan Konsumen.
}

gugat dikenal menjadi dua, yaitu tanggung gugat akibat melanggar hukum dan tanggung-gugat akibat melanggar perjanjian. Kedua tanggung gugat ini dirumuskan dalam ketentuan pasal 1370, 1371, dan pasal 1235 KUH Perdata. Bagi pihak yang merasa dirugikan haknya akibat adanya pelanggaran hukum atau perjanjian berhak mengajukan tuntutan ke pengadilan, baik secara pribadi maupun kelompok, dengan menyertakan alat bukti yang dapat meyakinkan pengadilan sehingga pelanggaran dapat diselesaikan sesuai dengan Undang-Undang. ${ }^{75}$

Lebih tegas tentang sanksi pelanggaran terhadap ketentuan produksi halal dikenakan sanksi administrastif dan/atau pidana sebagaimana diatur dalam Undang Nomor 33 Tahun 2014 tentang Jaminan Produk Halal. Ketentuan tentang berproduksi halal juga telah diatur dalam Undang-Undang ini. ${ }^{76}$

Penyimpangan atau pelanggaran terhadap ketentuan produksi halal atau iklan produk halal dengan penggunaan bahan yang diharamkan pernah dan masih terjadi oleh produsen. Sekedar untuk merefleksi kasus tahun 1988 berdasarkan hasil penelitian yang dilakukan terhadap beberapa produk makanan dan minuman, seperti susu, mie, snack diketahui bahwa produk-produk tersebut mengandung gelatin, shortening, lecithin, dan lemak yang kemungkinan berasal dari babi. ${ }^{77}$ Demikian juga dengan skandal penggunaan enzim yang berasal dari babi $^{78}$ (bacto zoyton) dalam monosodium gluttamat (MSG)

\footnotetext{
${ }^{75}$ Adrian Sutedi dalam Henry Campbell Black, Black Law Dictionary, h. 81.

76 Ditjen Bimas Islam Kemenag RI, Undang-Undang No. 33 Tahun 2014 tentang Jaminan Produk Halal., Jakarta, 2014. Pasal yang mangatur produksi halal dalam Bab III Bahan dan Proses Produk Halal pasal 17 ayat (1), (2) dan (3), pasal 18 ayat (1), Pasal 19 ayat 1 dan (2), Pasal 20 ayat 1(), (2) dn (3), Pasal 21 ayat (1), (2 ) dan (3).

${ }_{77}$ Penelitian tersebut kemudian dimuat dalam Buletin Canopy yang diterbitkan oleh Ikatan Mahasiswa Fakultas Peternakan Universitas Brawijaya Malang pada Januari 1988. Buletin ini tersebar luas ke beberapa wilayah di Jawa Timur. Selanjutnya, hasil penelitian Tri Susanto, dikaji oleh Asosiasi Cendekiawan Muslim Al-Falah Jawa Timur. Berawal dari kajian Asosiasi inilah kemudian timbul kegoncangan yang merebak di tengah kaum Muslimin di Provinsi Jawa Timur dan terus meluas ke provinsi-provinsi lainnya di Indonesia. Maka terjadilah demo besar-besaran yang dilancarkan warga muslim Indonesia yang memprotes adanya bahan-bahan dari babi pada pelbagai produk tersebut. Dampak dari isu tersebut berimbas pada guncangnya perekonomian nasional sehingga terancam lumpuh, karena masyarakat menjauhi produk-produk yang diisukan mengandung babi walaupun belum dibuktikan secara ilmiah. Hasil produk nasional turun hingga mencapai lebih dari $30 \%$ dari produksi normal. Bahkan produsen mie terbesar saat itu yang biasanya memproduksi sedikitnya 40 juta dus per bulan turun hingga hanya memproduksi 20 juta dus saja per bulannya.Tragedi nasional isu lemak babi ini begitu mengguncang ketenangan batin umat Islam, menyudutkan dunia industri pangan, dan mengguncang stabilitas ekonomi dan politik nasional.

${ }^{78}$ Berdasarkan skema yang dipublikasikan oleh LPPOM MUI tentang babi dan turunannya (pig and it's Derivatives) dijelaskan bahwa hampir seluruh anggota tubuh dari dapat merasuk ke dalam pelbagai jenis makanan dan bahan-bahan lainnya. Kulitnya, selain bisa menjadi aneka produk berbahan kulit seperti tas, sepatu, ikat pinggang, dompet
} 
Ajinomoto pada dasarnya isu terkait dengan product liability. Hal ini terkait dengan status halal produk ini. Sekalipun dalam menyikapi masalah ini ada perbedan penilaian mengenai kandungan bacto zoyton dalam MSG Ajinomoto antara LPPOM-(Lembaga Pengawas Obat dan Makanan Majelis Ulama Indonesia) dan BPOM. ${ }^{79}$

Berdasarkan hasil penelitian LPOM-MUI, Komisi Fatwa memutuskan keharaman MSG yang menggunakan bacto zoyton. Alasannya adalah bahwa bakteri dalam pembuatan MSG sudah terkena najis, karena diberi media pertumbuhan dengan bacto zayton yang dibuat dari enzim porcine yang ada dalam kemasan pankreas babi yang menyatu sedemikian rupa dan tidak pernah ada proses penyucian dengan cara yang diajarkan dalam agama Islam. Alasan lain yaitu didasari atas pengertian najis dalam ajaran Islam, yaitu najis

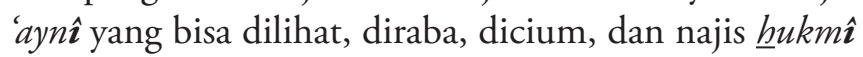
yang tidak terlihat, tercium, dan teraba. Dalam hal ini, Komisi Fatwa MUI mengklasifikasikan kadar haram bukan saja diakibatkan karena mengandung suatu hal yang diangap najis atau yang terlarang menurut ajaran agama Islam, tetapi tercampur dengan sesuatu yang dianggap haram dan najis pun sudah dianggap haram.

Sedangkan BPOM mengasumsikan halal atau tidaknya suatu poduk hanya didasarkan pada kandungan yang ada pada produk yang telah terjadi tersebut. Hal ini dapat dilihat pada hasl pemeriksaan mereka yang menyatakan bahwa residu enzim porcine tidak terdeteksi pada bumbu masak Ajinomoto. ${ }^{80}$ Asumi tersebut juga diperkuat dengan alasan bahwa enzim porcine yang merupakan campuran enzim yang diekstrakdari pankreas babi tersebut hanya berfungsi mempercepat reaksi pemecahan protein menjadi pepton (protein) yang kemudian enzim tersebut diendapkan dan disaring hingga tidak masuk dalam struktur produk. ${ }^{81}$

Dalam iklan melalui media televisi pihak Ajinomoto mengeluarkan iklan yang menggambarkan bahwa produknya layak digunakan oleh masyarakat yang beragama Islam. Jika iklan memuat informasi yang tidak benar, maka perbuatan itu memenuhi kriteria kejajahatan

sejenisnya juga bisa dijadikan bahan kolagen dan gelatin. Kolagen sendiri bisa menjadi bahan campuran kosmetika dan lapisan luar pada sosis. Sedang produk turunnya gelatin babi mengalir ke pelbagai produk olahan seperti es krim, yoghurt, marshmellow, permen, jelly hingga cangkng kapsul. Adapun lemak babi, produk turunannya bisa menjadi pelembab (texturizer) kosmetika, sabun dan lisptik.

79 Adrian Sutedi, Tangung Jawab Produk Dalam Hukum Perlindungan Konsumen, (Bogor: Ghalia Indonesia, 2008), Cet. I, h. 107. Lihat juga Kompas, "Kasus Ajinomoto Dihentikan”, Kamis, 9 Agusutus 2001. Lihat juga Kompas, "MSG Ajinomoto dipastika tidak mengandung Babi”. Kamis, 11 Januari 2001, h. 107.

${ }^{80}$ Produk tersebut saat halal dan telah mendapat sertifikat halal LPPOM -MUI.

${ }^{81}$ Adrian Sutedi, Tangung Jawab Produk Dalam Hukum Perlindungan Konsumen, h. 108. yang lazimnya disebut fraudulent misrepresentation. Hal ini menurut Sidharta ditandai oleh: (i) pemakaian pernyataan yang salah pilih (false statement); (ii) pernyataan yang menyesatkan (mislead). ${ }^{82}$ Di Amerika Serikat, berdasarkan section 2 (a) UDTPA, tindakan seperti ini dianggap sebagai praktik perdagangan yang mengelabui (deceptive trade practice). ${ }^{83}$

Jika dikaitkan dengan tanggung jawab jaminan produk halal yaitu dengan syarat halal sesuai dengan produk yang dinyatakan dalam iklan sebagaimana pada ketentuan peraturan perundang-undangan dinyatakan bahwa label atau iklan pangan yang diperdagangkan dengan persyaratan agama atau kepercayaan tentu bertanggungjawab atas kebenaan pernyataan berdasarkan persyaratan agama. ${ }^{84}$ Menurut Adrian Sutedi dalam kasus ini, penyebab iklan tersebut menjadi sifat mengelabui adalah karena apa yang diklankan tidak sesuai dengan kenyataan yang terdapat pada proses produksinya yang dalam hal ini bahwa produk tersebut halal menurut ajaran Islam, tetapi ternyata bila dilihat dalam perspektif ajaran Islam produk tersebut tidak dapat dikatakan halal karena dalam proses produksinya terjadi percampuran antara bahan MSG dengan material yang dinilai haram yaitu bacto zoyton.

Perlu dicatat, sebelum teknologi pengolahan pangan pesat berkembang seperti sekarang, persepsi masyarakat tentang keharaman sebuah produk masih sangat sederhana. Masalah halal haramnya makanan atau minuman hanya terkait dengan ada atau tidaknya produk yang mengandung babi atau mengandung alkohol. Makanan atau minuman yang bebas dari kedua bahan tersebut, otomatis dianggap halal. Namun kini, teknologi pengolahan pangan telah mengubah persepsi tersebut. Sebab produksi makanan untuk consumer goods tidak lagi hanya menggandalkan bahan utama saja, tetapi juga memerlukan bahan tambahan.

Dalam dunia industri makanan, kini dikenal pelbagai istilah seperti flavor (perisa), anti cacking agent, coloring agent, dan zat additive lainnya. Bahan-bahan itulah yang menjadikan penentuan halal tidaknya sebuah makanan atau makanan cukup rumit dan kompleks. Akivitas produksi yang beberapa waktu tidak pernah dikenal, atau bahkan tidk pernah tebayangkan, kini hal itu menjadi kenyataan. Zat seperti propelin glikol, traicetin, gkliserin/

${ }^{82}$ Sidharta, Hukum Perlindungan Konsumen Indonesia, (Jakarta: Grasindo, 2000), h. 20.

${ }^{83}$ Adrian Sutedi, Tangung Jawab Produk Dalam Hukum Perlindungan Konsumen, h. 95.

${ }^{84}$ Lihat UU Nomor 7 Tahun 1996 tentang Pangan pasal 1 angka 16 dan pasal 1 angka 4 PP Nomor 69 Tahun 1999 tentang Label dan Iklan Pangan, "Setiap orang yang menyatakan dalam label label atau iklan pangan yang diperdagangkan dengan persyaratan agama atau kepercayaan tentu bertanggungjawab atas kebenaan pernyataan berdasarkan persyaratan agama atau kepercayaan tersebut." 
gliserol umumnya digunakan sebagai solvent bagi flavor. Solvent tersebut umunya berasal dari hasil samping pembuatan sabun dan lilin yang direasikan dengan asam lemak dari minyak/lemak yang dapat berasal dari lemak hewan. Di sinilah letak titik kritis. Jika lemak hewani tersebut berasal dari barang yang haram seperti babi, maka hurumnya jelas haram. Begitu juga dari hewan halal seperti sapi, cara penyembelihannya tidak secara syariah.

Titik kritis lain dalam produski halal yang menyangkut dengan penggunan bahan haram yaitu darah. Berkaitan dengan masalah darah ini, selain kita memahami mengenai hukumnya darah pada aspek syari'ah sebagaimana telah diuraikan, maka kita juga perlu memperoleh informasi mengenai penggunaan darah pada produk, sebab seiring dengan kemajuan teknologi pangan sekarang ini, penggunaan darah pada produk sudah sangat luas. Di Indonesia sebagaimana dijelaskan oleh Anton Apriyantono di beberapa daerah darah beku (dikenal dengan nama dadih atau marus) dimakan yaitu dengan digoreng atau direbus, padahal jelas haramanya. Di negara-negara Eropa darah juga dimakan, namun jarang dalam bentuk dadih tetapi dibuat menjadi produk sosis. Di Jerman dikenal pelbagai bentuk sosis yang menggunakan bahan baku darah seperti sosis lidah, sosis darah, dan tetelan.

Penggunaan darah selain diolah untuk menjadi marus, atau dibuat menjadi sosis darah juga dapat dikeringkan langsung dan diolah menjadi tepung darah yang berfungsi baik sebagai bahan pakan (makanan ternak) atau pun ditambahkan ke dalam pangan olahan tertentu dengan maksud untuk mempertinggi nilai gizinya (besi atau protein). Di samping itu, tepung dapat berfungsi sebagai bahan pengikat atau bahan pengisi yang dapat memperbaiki flavour atau mutu pangan olahan, misalnya darah kering ditambahkan ke dalam sosis agar warna sosis dan daya ikat air sosis menjadi lebih baik. Darah, terutama darah kering juga dapat digunakan sebagai pewarna merah dalam makanan.

Belajar dari kasus tersebut, kondisi dan fenomena yang demikian ini, pada satu pihak mempunyai manfaat bagi konsumen akan barang dan jasa yang diinginkan dapat terpenuhi. Kepentingan konsumen Muslim terlindungi dari produk pangan kedaluwarsa atau produk haram. Di sisi lain, agar produsen atau pengusaha dalam membuat barang dan jasa harus memenuhi standar mutu barang yang dinilai dari penggunaan bahan baku, peralatan, proses produksi, orang yang terlibat dalam proses produksi, isi atau berat bersih harus sesuai dan menggunakan tanda atau label halal atau penggunaan tanda atau lebel lainnya. Dari pembahasan di atas tampak bahwa produsen halal harus mempertimbangkan disamping aspek hukum, juga tanggung jawab moral dari usaha mereka dalam memproses produksi produk halal.

Pada masa transisi pelaksanaan jaminan halal sampai terbentuknya Badan Jaminan Halal (BPJH). Di Indonesia, selama masa tersebut, perusahaan harus dapat memberikan jaminan kepada MUI dan konsumen muslim bahwa perusahaan senantiasa menjaga konsistensi kehalalan produknya. Oleh karena itu LPPOM MUI mewajibkan perusahaan untuk menyusun suatu sistem yang disebut Sistem Jaminan Halal (SJH) dan terdokumentasi sebagai Manual SJH. Manual ini disusun oleh produsen sesuai dengan kondisi perusahaannya. ${ }^{85}$

Sebelas prinsip SJH yang diberlakukan LPPOMMUI dalam berproduksi halal bagi produsen yang telah memperoleh sertifikat halal bahwa prinsip tersebut adalah berpandukan kepada kaedah syariah dan kaidah fikih (قواعد فقهيa) serta pendapat ulama berlandaskan kepad Alquran dan Hadis seperti maqâshid al-syarîah, kesucian, dan kejujuran.

Di Malaysia, tanggung jawab produk halal bagi para produsen bagi para produsen halal wajib mematuhi peraturan dan standard halal sehingga dapat diberikan sertifikat halal. Standar dan peraturan yang perlu dipatuhi oleh produsen halal yaitu: (i) Manual Prosedur Pensijilan Halal Malaysia (MPPHM); (ii) Standard Halal Malaysia MS 1500:2004 (Makan halal, pengeluaran penyediaan, pengendalian, dan penyimpanan serta Garis Panduan Umum); (iii) Good Manufacturing Practice (GMP), Guidelines on Good Hygiene Practice for Small and Medium Scale Food Industries Toward HACC; (iv) Akta Perihal Perdagangan; dan (v) Akta Makanan. ${ }^{86}$

Makanan dan minuman yang bersih suci mengikuti panduan halal di Malaysia memenuhi beberapa ciri, yakni (1) Produk tidak terdiri atas bahagian atau benda hewan yang larang oleh syarian memakannya atau tidak disembelih mengiktu hukum syarak; (2) Produk mengandung najis sesuai sebagaimna ditetapkan pada ketentuan hukum syara seperti minyak babi, lemak bangkai atau jenis khamr atau arak; (3) Pada proses produksi alat yang digunakan bebas dari najis; (4) Produk tidak bercampur dengan benda yang haram selama proses seperti penyediaan, atau penyimpanannya; (5) Pekerja-pekerja diperusahaan mestilah sehat, bersih, dan mempraktikkan kode etik kebersihan dn kesehatan; (6) Peralatan yang digunakan telah dibasuh dan suci. Cara membasuh adalah dengan air bersih dan mengalir; (7) Kebersihan peralatan, pengangkutan dan lingkungan

\footnotetext{
${ }^{85}$ lihat Panduan Jaminan Halal, LPPOM-MUI.

${ }^{86}$ Sezelin binti Arif, Integriti Usahawan Makan Halal Thayyiban sebagai Standard Piawaian, (Malaysia: Majelis Perundingan Islam, Jabatan Kemajuan Islam, Malaysia, 2009 M/1430 H), h. 682.
} 
pabrik dan atau menerapkan good manufacturing practice; (8) Pengemasan dan pemindahan produk menerapkan etik kebersihan dan tidak mengandung ramuan yang tidak halal sebagaimana ketentuan syara.

\section{Penutup}

Pemahaman dan keperluan kepada ketentuan syariah mengenai halal, haram, dan syubhat yang berlandaskan Alquran dan Hadis serta pendapat para fukaha amat penting dan menjadi panduan oleh konsumen dan produsen dalam memproduksi produk halal. Panduan jaminan halal di Indonesia diterapkan dalam sistem jaminan halal (SJH). Setiap produk halal yang diedarkan produsen harus dapat ditanggung-gugat terhadap produknya.[]

\section{Pustaka Acuan}

Kementerian Agama, Al-Qur'an dan Terjemahnya.

Arif, Sezelin binti, Integriti Usahawan Makan Halal Thayyiban sebagai Standard Piawaian, Malaysia: Majelis Perundingan Islam, Jabatan Kemajuan Islam, Malaysia, $2009 \mathrm{M} / 1430 \mathrm{H}$.

Baghawî, al-, Abû Muhammad al- $\underline{\text { Hu}} u s a y n$ bin Mas'ud, Ma'âlim Tanzîl, Dâr Thibah, Majma’Malik Fahad, 1417 H-1997 M.

Ditjen Bimas Islam Kemenag RI, Undang -Undang No. 33 Tahun 2014 tentang Jaminan Produk Halal, Jakarta, 2014.

Esposito, John L., Ensiklopedi Oxford Dunia Islam Modern, Penerjemah, Eva YN, dkk, Bandung: Penerbit Mizan, 2001.

Ghazalî, al-, Muhammad ibn Muhamammad Abû Hâamid, Mukhtashar Ihyầ' 'Ulûm al-Dîn, Bayrût: Dâr al-Fikr, $1406 \mathrm{H}-1986 \mathrm{M}$.

Ibn al-'Arabî, Abû Bakr Muhammad ibn 'Abd Allâh,

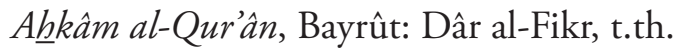

Ibn al-Sa'di, 'Abd al-Raḩmân ibn Nâshir ibn, Taysîr alKarîm al-Raḥman fi Tafsî̀ al-Kalâm al-Mannân, ditahqî̀q oleh 'Abd al-Rahmân ibn Ma'lâ al-Luwayhik, Mu'assasah al-Risâlah, Malik Fahd, 1420H-2000M.

Ibn Hazm al-Andalusi, Marâtib al-Ijma’, Dar al-Âfâq al Jadîdah, t.th.

Ibn Katsîr, Abî al-Fida al-Hââfizh, Tafsîr al-Qur'ân al-Azhîm, jilid II, III, Bayrût: Dâr al-Fikr, 1412H-1992M.

Imâdî, al-, Abû al-Sảud Muhammad ibn Muhammad ibn Musthafâ, Mufradât al-Qur'ân, Versi Maktabah Syamilah.
Jashshash, al-, Abû Bakr Ahmad al-Râzî, Ahkâm alQur'ân, Bayrût: Dâr al-Fikr, 1414 H/1993M.

Jurjani, al-, 'Alî ibn Muhammad ibn 'Alî, Al-Tárîfât, Tạhqîq Ibrâhîm al-Abyarî, Bayrût: Dâr al-Kitâb al'Arabî, $1405 \mathrm{H}$.

Kalabi, al-, Abû al-Qâsim Muhammad ibn Aḥmad ibn Juzai, Al-Qawânîn al-Fiqhiyyah, Dâr Ibn Hazm, 1997.

LPPOM-MUI, Panduan Jaminan Halal.

Madjid, Nurcholis, Makna Kejatuhan Manusia ke Bumi, dalam Islam Agama Peradaban, Jkarta: Paramadina, 2000.

Mubarakfuri, al-, al-ㅌâfizh Abî al-Ulâ Muhammad 'Abd al-Rahmân ibn 'Abd al-Rahîm, Tuhfah alAhwadzi, Bayrût: Dâr al-Fikr, 1424H-2003M.

Nasution, Az., Hukum Perlindungan Konsumen Suatu Pengantar, Yogyakarta, Diadit Media, 2001.

Nawawî, al-, Imâm Abî Zakariyyâ Yahyya ibn Syaraf, Syarh Muslim, Bayrût: Dâr al-Fikr, 421H-2000M.

Peraturan Pemerintah Nomor 69 Tahun 1999 tentang Label dan Iklan Pangan.

Qal'ajî, Muhammad Rawas Qal'ajî dan Qanaybî, Muhammad Sadiq, Mu'jam Lughah al-Fuqahâ, Bayrût: Dâr al-Fikr, 1405 H-1985 M.

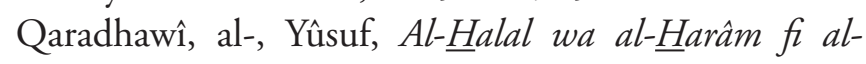
Islâm, terjemah Wahid Amadi dkk, Halal Haram dalam Islam, Solo: Era Intermedia, 1424H-2003 M.

Qurthubî, al-, Muhammad ibn Aḥmad ibn Muhammad ibn Rasyîd, Bidâyah al-Mujtahid wa Nihâyah alMuqtashid, Jilid I, Dâr al-Kutub al-Islamiyyah.

Sakr, Ahmad H., Understanding Halal Foods Fallacies \& facts, Lombard: Foundation For Islamic knowledge, 1996.

Shâbûnî, al-, Muhammad 'Alî, Shafwah al-Tafâsîr, Bayrût: Dâr al-Fikr, t.th.

Sidharta, Hukum Perlindungan Konsumen Indonesia, Jakarta: Grasindo, 2000.

Sutedi, Adrian dalam Henry Campbell Black, Black Law Dictionary, Sixth Edition, St Paul Minnesota, West Publishin Company, 1983.

Adrian dalam Ray H. Anderson, Current Problem in Product Liability Law and Product Liability Insurance, Insurance Counsel Journal, July, 1964.

Suyuthî, al-, Jalâl al-Dîn, dalam Lubaâb al-Nuqûl fi Asbâb al-Nuzûl, Maktabah al-Qahirah, al-Duwaliyah.

Syawkânî, al-, Fath al-Qâdir, Bayrût: Dâr al-Ma'rifah, 2007.

Thabarî, al-, Muhammad ibn Jarîr ibn Yazîd ibn Katsîr ibn Ghâlib al-Amalî Abû Ja'far, Jâmi al-Bayân fi Tảwil al-Qur'ân, di-tahqiq oleh Ahmad Muhammad Syakir, Penerbit Muassah al-Risalah, Cetakan Malik Fahad.

Undang-Undang Nomor 7 Tahun 1996 tentang Pangan. 